\title{
The Olympic Cu-Au Province, Gawler Craton: A Review of the Lithospheric Architecture, Geodynamic Setting, Alteration Systems, Cover Successions and Prospectivity
}

\author{
Anthony Reid 1,2 (1) \\ 1 Geological Survey of South Australia, Department for Energy and Mining, Adelaide, SA 5001, Australia; \\ anthony.reid@sa.gov.au; Tel.: +61-8-8463-3000 \\ 2 Department of Earth Sciences, University of Adelaide, Adelaide, SA 5005, Australia
}

Received: 29 May 2019; Accepted: 19 June 2019; Published: 20 June 2019

check for updates

\begin{abstract}
The Olympic $\mathrm{Cu}-\mathrm{Au}$ Province is a metallogenic province in South Australia that contains one of the world's most significant $\mathrm{Cu}-\mathrm{Au}-\mathrm{U}$ resources in the Olympic Dam deposit. The Olympic $\mathrm{Cu}-\mathrm{Au}$ Province also hosts a range of other iron oxide-copper-gold (IOCG) deposits including Prominent Hill and Carrapateena. This paper reviews the geology of the Olympic $\mathrm{Cu}$-Au Province by investigating the lithospheric architecture, geodynamic setting and alteration systematics. In addition, since the province is almost entirely buried by post-mineral cover, the sedimentary cover sequences are also reviewed. The Olympic Cu-Au Province formed during the early Mesoproterozoic, ca. 1.6 Ga and is co-located with a fundamental lithospheric boundary in the eastern Gawler Craton. This metallogenic event was driven in part by melting of a fertile, metasomatized sub-continental lithospheric mantle during a major regional tectonothermal event. Fluid evolution and multiple fluid mixing resulted in alteration assemblages that range from albite, magnetite and other higher temperature minerals to lower temperature assemblages such as hematite, sericite and chlorite. IOCG mineralisation is associated with both high and low temperature assemblages, however, hematite-rich IOCGs are the most economically significant. Burial by Mesoproterzoic and Neoproterozoic-Cambrian sedimentary successions preserved the Olympic $\mathrm{Cu}$-Au Province from erosion, while also providing a challenge for mineral exploration in the region. Mineral potential modelling identifies regions within the Olympic $\mathrm{Cu}-\mathrm{Au}$ Province and adjacent Curnamona Province that have high prospects for future IOCG discoveries. Exploration success will rely on improvements in existing potential field and geochemical data, and be bolstered by new 3D magnetotelluric surveys. However, drilling remains the final method for discovery of new mineral resources.
\end{abstract}

Keywords: IOCG deposits; mineral district; mineral deposit; alteration assemblages; lithosphere; metallogenesis

\section{Introduction}

World demand for copper, gold and other metallic commodities continues to grow. The iron oxide-copper-gold (IOCG) class of deposits is highly significant sources of these key metals and is a significant target for mineral exploration. IOCG deposits are recognized as a distinct albeit varied deposit class in large part as a result of the discovery, development and study of the Olympic Dam $\mathrm{Cu}-\mathrm{Au}-\mathrm{U}$ deposit in South Australia [1,2]. Since that time, the similarities between Olympic Dam, other deposits of the eastern Gawler Craton and a range of related deposits world-wide has been recognized [3,4]. The diverse range of deposits included in this broad envelope span a range of geologic time and include those within the Archean Carajas Disctrict [5]; Proterozoic terranes such as 
the Curnamona Province [6], Tenant Creek [7], Mt Isa [8], Wernecke [9], and the Great Bear [10]; and Mesozoic deposits in the Andes [11,12]. There is a diversity within the IOCG deposits in terms of the mineralogy of the iron oxide phase, with the terms 'hematite-group' and 'magnetite-group' having been introduced in recognition of the differences in physico-chemical conditions under which iron oxides can precipitate to form these deposits [13-15]. The sources of fluids associated with IOCG deposits can vary from magmatic to sedimentary, which has implications for both the sources of metals and ligands such as sulphur (e.g., [8,9,16-18]). Furthermore, there is a large spectrum of alteration minerals associated with IOCG deposits that appear to record a systematic response to changing fluid temperatures and fluid-rock interaction (e.g., [19]). Finally, IOCG deposits are economic sources of other elements like uranium, iron, lead, zinc, silver, bismuth and rare earth elements, in addition to the main ore forming elements copper and gold [2-4]. Diversity is indeed a hallmark of the IOCG deposit class.

Olympic Dam is a highly significant deposit containing the world's fifth largest copper and third largest gold resource and is the world's largest uranium deposit [20]. The deposit lies within a region of the eastern Gawler Craton known as the Olympic $\mathrm{Cu}$-Au Province, a metallogenic province of $\sim 600 \mathrm{~km}$ strike length (Figure 1) [21]. There are now numerous studies on the geology of individual deposits within the Olympic $\mathrm{Cu}$-Au Province [22-25], including a number of papers related to Olympic Dam itself (e.g., [20,26-29]), and several reviews of the broader geodynamic setting within which these deposits formed (e.g., [30-32]). Potential exists for further discovery of significant mineral deposits in this region [33], however, as the Olympic $\mathrm{Cu}$-Au Province is almost entirely covered by Neoproterozoic and Phanerozoic sediment, exploration in this region remains a challenging task.

The purpose of this paper is to provide a review of the geology of the Olympic $\mathrm{Cu}$-Au Province. The approach taken here is to describe this IOCG district with reference to four major themes:

1. the architecture of the lithosphere in the Gawler Craton and the eastern Gawler Craton in particular, in order to understand the broad structural architecture within which the IOCG mineral system developed;

2. the geodynamic evolution of the major tectonic event during which the IOCG deposits formed that provided the energy drivers and structural control on the localization of the mineral system;

3. the mineral and chemical footprints of the Olympic Dam mineral system in the upper crust, which are significant for exploration vectoring; and,

4. the character of the cover successions overlying the prospective Proterozoic basement in the region, since understanding the cover geology is necessary for effective exploration and because they are themselves host to copper mineralisation.

In addition, the mineral potential of this region is reviewed with reference to modelling conducted using mineral systems and geographic information systems (GIS) approaches. A brief description of the lithostratigraphy of the Gawler Craton and relevant adjacent terranes of southern Australia, the Curnamona Province and Adelaide Rift Complex is first provided.

The Olympic $\mathrm{Cu}-\mathrm{Au}$ Province remains an attractive destination for mineral exploration. Assisted by the increasing data richness, this province can be viewed as a natural laboratory with which to study a world class mineral system (e.g., [34-36]). This mineral system is a result of the interplay between an enriched lithospheric mantle, lithospheric-scale heat and mass transfer, intense regional fluid flow and the preservation of mineralisation as a result of a subdued post-mineralisation evolution dominated by burial beneath sedimentary cover. 


\section{Geological Setting}

The Gawler Craton and Curnamona Province form the core of a broader geological entity, known as the South Australian Craton [37]. Prior to opening of the Southern Ocean as a result of Cretaceous rifting, the South Australian Craton was connected to the Terrie Adelie Craton and likely related terranes of Antarctica, forming a broader terrane known as the Mawson Continent (e.g., [38,39]). During the Proterozoic it is likely that the Mawson Continent itself was connected to portions of Laurentia in varying configurations associated with the continental amalgamation of Nuna (e.g., [40]). There are also potential links between the Archean portions of the Gawler Craton and other terranes of Nuna including the Sask Craton based on event timing and style of reworking in the late Archean and early Paleoproterozoic (e.g., [41,42]).

The Gawler Craton (Figures 1 and 2) contains Meso-Neoarchean-earliest Paleoproterozoic basement complexes that comprise ca. $3150 \mathrm{Ma}$ granites and granite gneisses [43], along with ca. 2555-2480 Ma supracrustal sequences that include mafic and felsic volcanics with possible continental arc affinities [44,45] and mafic and ultramafic volcanics including a ca. 2520 Ma komatiite succession [46]. These basement complexes are overlain by Paleoproterozoic volcano-sedimentary successions deposited between ca. 2000 and ca. $1740 \mathrm{Ma}$ (e.g., [47]). Intrusive magmatism and associated localized deformation occurred at ca. $1850 \mathrm{Ma}$ although deposition of the volcano-sedimentary rocks was terminated during a major tectono-metamorphic event at ca. 1735-1690 Ma (Kimban Orogeny [30]). Post-orogenic magmatism [48] and localized basin formation occurred subsequent to this event [49]. The Paleoproterozoic to Mesoproterozoic transition was a time of significant magmatism, with the juvenile, arc-related intrusions of the ca. 1635-1604 Ma St Peter Suite forming the in south-western region of the Gawler Craton $[50,51]$ and the widespread bimodal volcanic and intrusive activity during formation of the ca. 1595-1575 Ma Gawler Range Volcanics and Hiltaba Suite [52,53]. The latter event was associated with regionally partitioned deformation and metamorphism that is generally referred to as the Kararan Orogeny [30,54]. This major orogenic event was widespread across the Gawler Craton and has been shown to include examples of ultra-high temperature metamorphism in the northern Gawler Craton [55] and deformation during magmatic emplacement in the southern Gawler Craton [56].

The ca. 1595-1575 Ma event also saw the formation of the IOCG deposits in the Olympic $\mathrm{Cu}-\mathrm{Au}$ Province and a series of gold-dominated, structurally controlled mesothermal deposits grouped together as the Central Gawler Gold Province (Figure 1) [57,58]. Reworking along major shear zones together with localized deformation and metamorphism occurred subsequently between ca. $1515 \mathrm{Ma}$ and ca. $1450 \mathrm{Ma}$ [59-62]. Overlying the eastern region of the Gawler Craton are continental sediments of the Pandurra Formation, a remnant of the Carriwerloo Basin deposited at ca. 1450 Ma (Figure 3) [52,63]. 


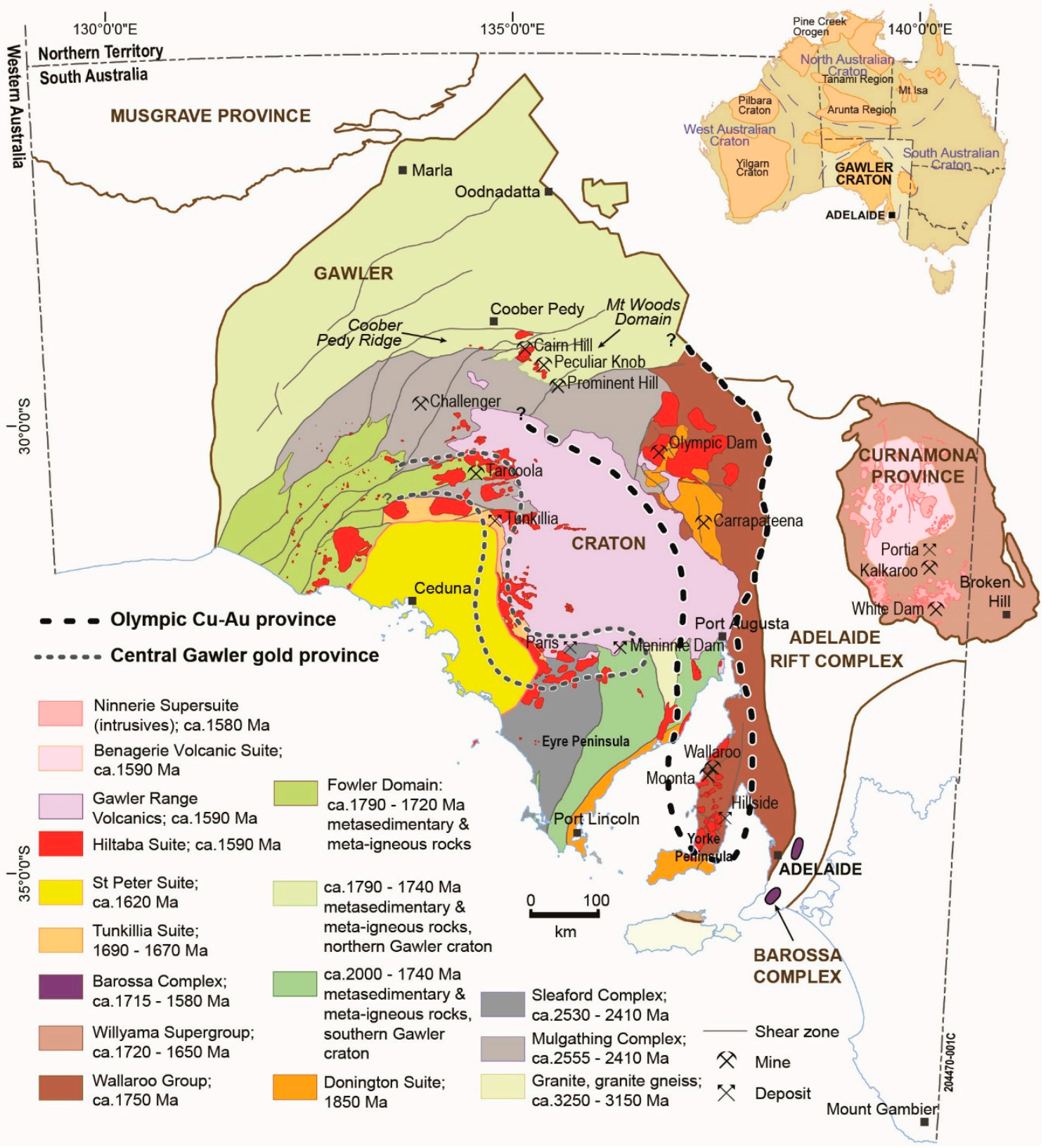

Figure 1. The Olympic $\mathrm{Cu}-\mathrm{Au}$ Province in the context of the geology of southern Australia. The main lithotectonic units of the Gawler Craton and Curnamona Province are shown and are interpreted from surface observation and geophysical data. The Olympic $\mathrm{Cu}-\mathrm{Au}$ Province occurs in the eastern Gawler Craton and also indicated is the Central Gawler Gold Province, a gold-dominated metallogenic province formed during the same early Mesoproterozoic tectonic event that formed the Olympic $\mathrm{Cu}-\mathrm{Au}$ Province. Inset shows the location of the Gawler Craton and Curnamona Province in the context of major Archean and Proterozoic terranes of Australia. Modified from [64]. 
The Curnamona Province is dominated by metasedimentary and meta-igneous units of the Willyama Supergroup, ca. 1720-1640 Ma. The Willyama Supergroup was largely deposited in an intracontinental rift setting and accompanied by mafic and felsic magmatism [65] during which exhalative-type processes resulted in formation of the Broken Hill Zn-Pb-Ag orebody (e.g., [66,67]). These packages were intruded by granites of the Ninnerie Supersuite and in the western regions overlain by bimodal volcanics of the Benagerie Volcanic Suite during the early Mesoproterozoic, ca. 1595-1575 Ma [68]. These early Mesoproterozoic suites have geochemical and temporal affinities with the Hiltaba Suite and Gawler Range Volcanics of the Gawler Craton (e.g., [69]). Formation of these magmatic rocks was broadly synchronous with deformation and metamorphism during the Olarian Orogeny [70]. This event appears to have begun some time prior to intrusion of the oldest granites of the Ninnerie Supersuite, with monazite and early burial metamorphism occurring at ca. 1620 Ma [71] potentially coupled with formation of early hydrothermal replacement $\mathrm{Cu}$-Au mineralisation [72,73]. Nevertheless, the main $\mathrm{Cu}$-Au deposits of the Curnamona Province such as the Kalkaroo deposit appear to have formed at ca. $1590 \mathrm{Ma}$, and therefore at broadly the same time as those of the hematite-group IOCG systems of the Olympic Cu-Au Province (see also [32,73]).

The Adelaide Rift Complex, or Adelaide Geosyncline, comprises a series of rift and sag basins that initiated during the Neoproterozoic at ca. $820 \mathrm{Ma}$ and continued into the early Cambrian [74]. This rifting was related to break-up of Rodinia [75]. A wedge of Neoproterozoic to Cambrian platform cover overlies the eastern Gawler Craton and is termed the Stuart Shelf, with the Torrens Hinge Zone being the structural corridor separating the platform sediments from the main rift complex [76] (Figure 3).

Crystalline basement to the Adelaide Rift Complex, known as the Barossa Complex, is of similar age and composition to portions of both the Gawler Craton and Curnamona Province, supporting interpretations of their former juxtaposition [77]. The Barossa Complex includes both metasedimentary and meta-igneous units. Metasedimentary units were deposited at ca. 1730-1655 Ma and felsic intrusions have been dated at ca. $1720 \mathrm{Ma}$ (Figure 2) [78]. Peak granulite facies metamorphism occurred at ca. $1590 \mathrm{Ma}$, with conditions of approximately 8-9 kbar and $800-850{ }^{\circ} \mathrm{C}$ synchronous with the Kararan Orogeny of the Gawler Craton and Olarian Orogeny of the Curnamona Province [79]. 


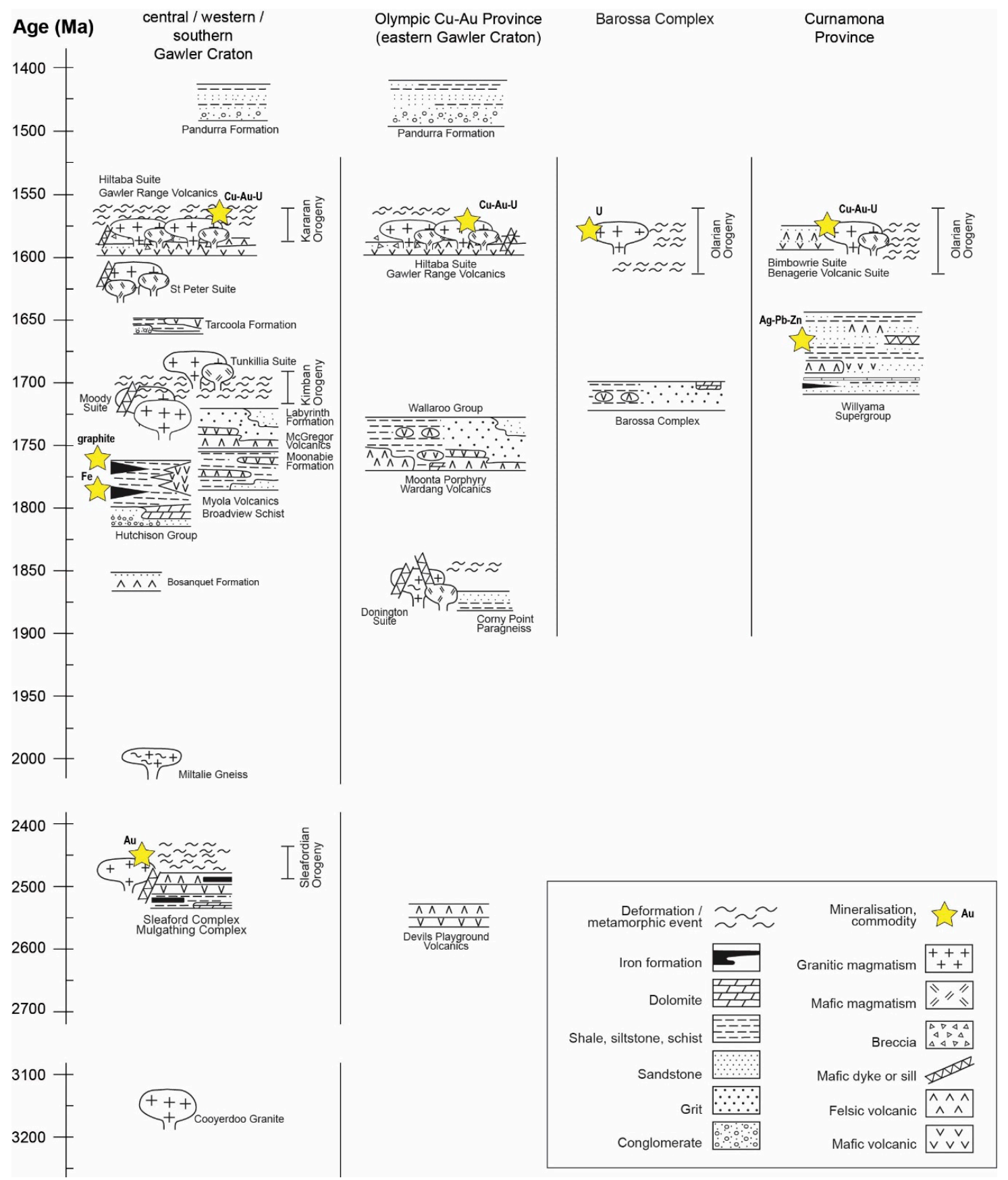

Figure 2. Simplified time-space diagram illustrating the main lithotectonic elements of the Gawler Craton, Barossa Complex and Curnamona Province. This figure also highlights some of the lithotectonic differences between the eastern and western Gawler Craton, with the region of the Olympic $\mathrm{Cu}-\mathrm{Au}$ Province broadly equivalent to the eastern Gawler Craton. For discussion see [80]. 


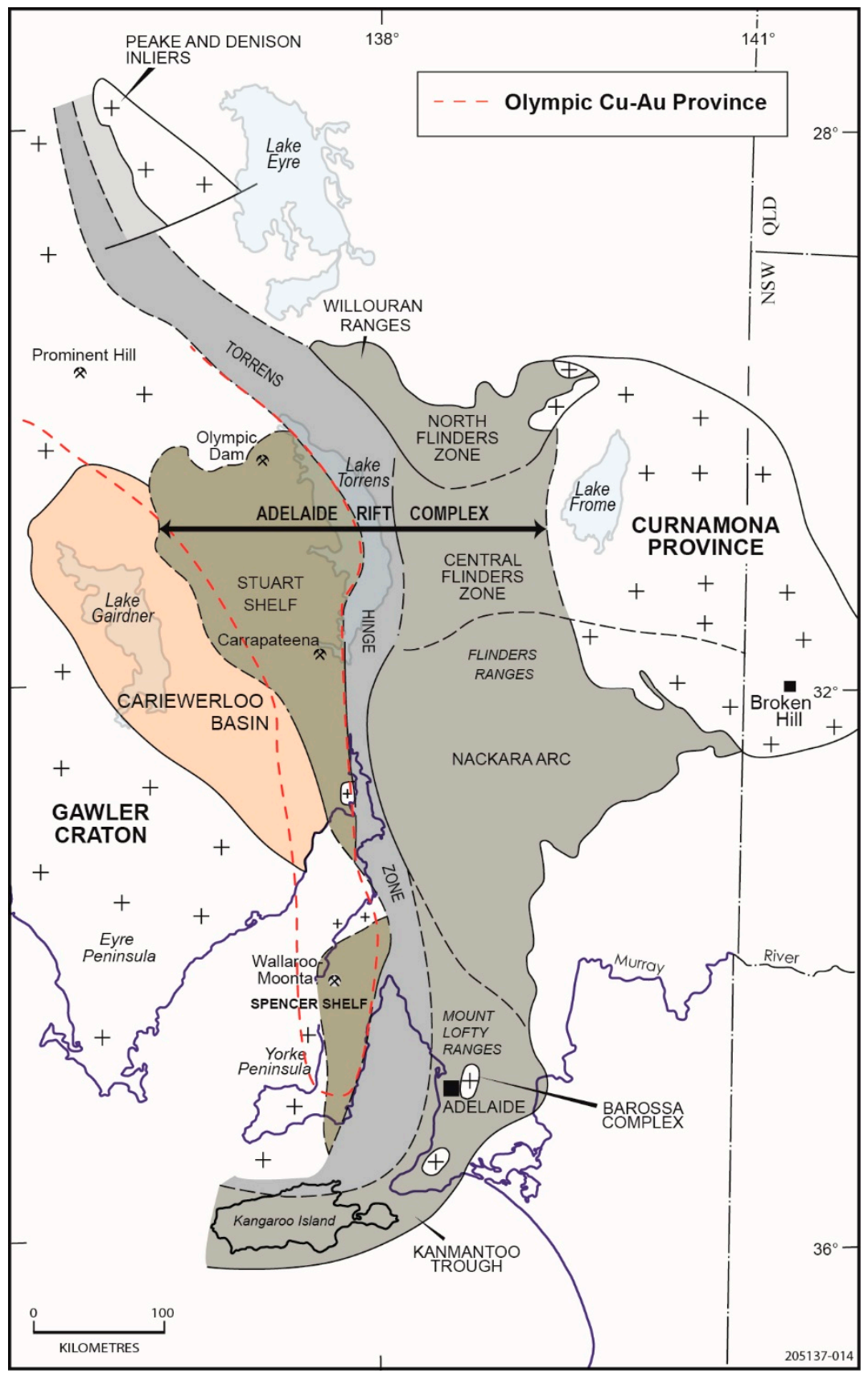

Figure 3. Location of the Carriwerloo Basin, Stuart Shelf and the subdivisions of the Adelaide Rift Complex with respect to the Gawler Craton and Curnamona Province.

Early Cambrian extension in the southern region of the Adelaide Rift Complex led to formation of a deep basin, the Kanmantoo Trough, likely as a related to back-arc extension inboard of a Cambrian subduction system $[81,82]$. Deposition was terminated by the Delamerian Orogeny at ca. 510-480 Ma, which resulted in regional-scale fold-thrust systems, variable degrees of high temperature-low pressure metamorphism and extensive granite intrusion particularly in the south $[83,84]$. While the central axis and eastern regions of the Adelaide Rift Complex was affected by the Delamerian Orogeny, sedimentary units of the Stuart Shelf remained largely undisturbed, likely shielded by rigid Gawler Craton lithosphere during regional compression [82].

The majority of the Gawler Craton and Curnamona Province lie buried beneath a veneer of Phanerozoic sedimentary rocks that include successions of the Mesozoic Eromanga Basin [85], the Eocene-Miocene Eucla Basin in the south-east [86] and Plio-Pleistocene aeolian dunefields. 


\section{Lithospheric Architecture of the Olympic Cu-Au Province}

Continental-scale seismic tomography datasets reveal the lithosphere-asthenosphere boundary beneath the Gawler Craton reaches maximum thicknesses of 180 to $220 \mathrm{~km}$, with the thickest portion occurring beneath the central Gawler Craton [87]. The depth of the Moho is variable across the Gawler Craton. In the central Gawler Craton, the Moho lies at $\sim 18 \mathrm{~s}$ two way time (TWT), $\sim 54 \mathrm{~km}$, yet is considerably shallower in the northern Gawler Craton $\sim 12 \mathrm{~s}$ TWT or $\sim 36 \mathrm{~km}$. This difference is related to offsets across north-dipping trans-crustal faults [88]. In the eastern Gawler Craton, to the immediate southwest of the Olympic Dam, the Moho lies at $\sim 13 \mathrm{~s}$ TWT, $\sim 39 \mathrm{~km}$ and becomes slightly deeper to the northeast where it is imaged at $\sim 14 \mathrm{~s}$ TWT or $\sim 42 \mathrm{~km}$ [89]. Seismic reflection data from a section across the Olympic Dam (Figure 4) yield key observations on the crustal structure of the region. The original processed seismic data shows an offset in the Moho beneath Olympic Dam with slightly thicker crust to the north of the deposit. The Moho offset suggests Olympic Dam lies above a large crustal-scale fault zone.

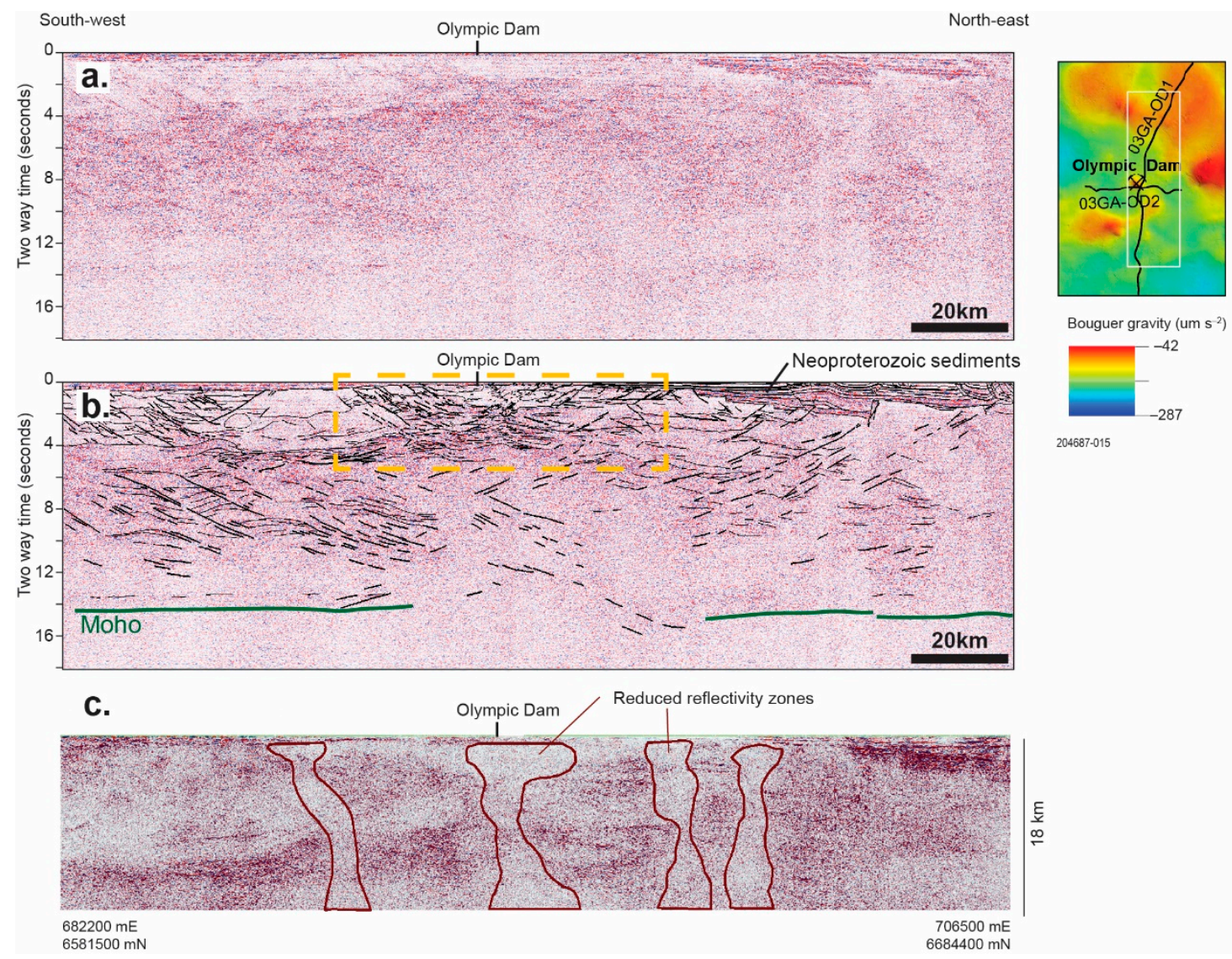

Figure 4. Reflection seismic images across Olympic Dam region, eastern Gawler Craton. Seismic line 03GA-OD1 of Geoscience Australia. (a) Uninterpreted seismic reflection data from [89]. (b) Interpretations of seismic reflection data simplified after [89]. (c) Detail of Olympic Dam region upper crust with data reprocessed to enhance vertical structural elements after [90].

These seismic data also reveal a zone of lower amplitude reflectivity, or 'bland zone', in the region immediately beneath Olympic Dam extending from a depth of approximately $20 \mathrm{~km}$ to the base of the crust. These observations suggest that the crust directly beneath Olympic Dam has been subject to a tectonic process that has modified the seismic character of the rock packages in the lower crust. The most obvious candidates for this type of reworking are fluid and or magmatic reworking $[89,90]$. 
Reprocessing of the original seismic data has been undertaken with a method whose processing technique emphasizes higher frequency variations in the seismic reflection data [90]. This type of processing has the effect of sharpening the output image and was designed enhance upper crustal features. This resulting processed image indicates the presence of sub-vertical breaks in the reflectivity structure in the upper crust (Figure 4c) [90]. These subvertical breaks in seismic character are interpreted to be caused by pervasive textural destruction of the crust at the scale of $>15 \mathrm{~km}$ thickness and 5-10 km wide. Processes such as migration of fluids such as hydrothermal fluids or partial melt associated with localized deformation could result in this type of texture and may indicate the specific channels through which fluids that caused the IOCG deposits were channelized in the Mesoproterozoic.

At the lithospheric scale, seismic tomography data identify distinct zones of variable $\mathrm{S}$ and $\mathrm{P}$ wave speed in the Gawler Craton mantle [32]. The variable wave speeds indicate compositional heterogeneity at the broad scale in the Gawler Craton mantle. Beneath the Olympic $\mathrm{Cu}-\mathrm{Au}$ Province the mantle has unusually high ratios of compressional- to shear-wave velocities ( $\mathrm{Vp} / \mathrm{Vsh}>1.80)$, which Skirrow, et al. [32] interpreted to reflect the presence of peridotite mantle beneath this region comprising hydrated olivine (e.g., clinohumite), garnet and phlogopite. The presence of hydrated mantle lithosphere is evidence for the focusing of metasomatic alteration of pre-existing, anhydrous mantle lithosphere in the region of the Olympic $\mathrm{Cu}-\mathrm{Au}$ Province.

Compositional heterogeneity of the Gawler Craton lithosphere is also evident in regional magnetotelluric data. Large regions of the central and western Gawler Craton have electrically resistive mantle lithosphere, with conductivity values $(>1000 \Omega \mathrm{m})$ typical for Archean lithosphere (Figure 5) [91-94]. In contrast, a north-west-south-east oriented electrically conductive zone occurs at depths of $\sim 150-100 \mathrm{~km}$ beneath the central-eastern Gawler Craton, with the region to the north-east of Olympic Dam being more conductive than the region to the south-west [93].

The Gawler Craton IOCG deposits appear to be linked to a major crustal and indeed lithospheric scale boundary. This boundary lies along a north-west trend and its presence is confirmed by changes in mantle and lower crustal conductivity, gradients in seismic wave speed, variations in satellite gravity and isotopic data from magmatic rocks (e.g., [32,95-97]). Lithospheric scale boundaries are critical elements of mineral systems as they are typically weaker and reactivate during strain, thereby providing fluid and mass conduits that connect the mantle to the crust (e.g., $[98,99])$.

Evidence for the focusing of fluids and or magmas related to the IOCG province comes from long period and broadband magnetotelluric surveys along the 03GA-OD1 seismic traverse (Figure 5b) $[93,100]$. Resistivity models along this traverse reveal subvertical zones of enhanced conductivity extends into the upper crust, with progressively narrower zones of high conductivity appearing to connect with several known IOCG prospects and deposits, including Olympic Dam $[90,92,100]$. These subvertical structures extending into the upper crust mimic the destruction of seismic texture recorded in the reprocessed seismic images (Figure 4c) [90]. In this respect, this lithospheric boundary appears to have set up the architecture within which the IOCG systems of the Olympic $\mathrm{Cu}-\mathrm{Au}$ Province formed, with related structures channeling magmas and associated metasomatic fluids into the middle and upper crust during the mineralizing event. 


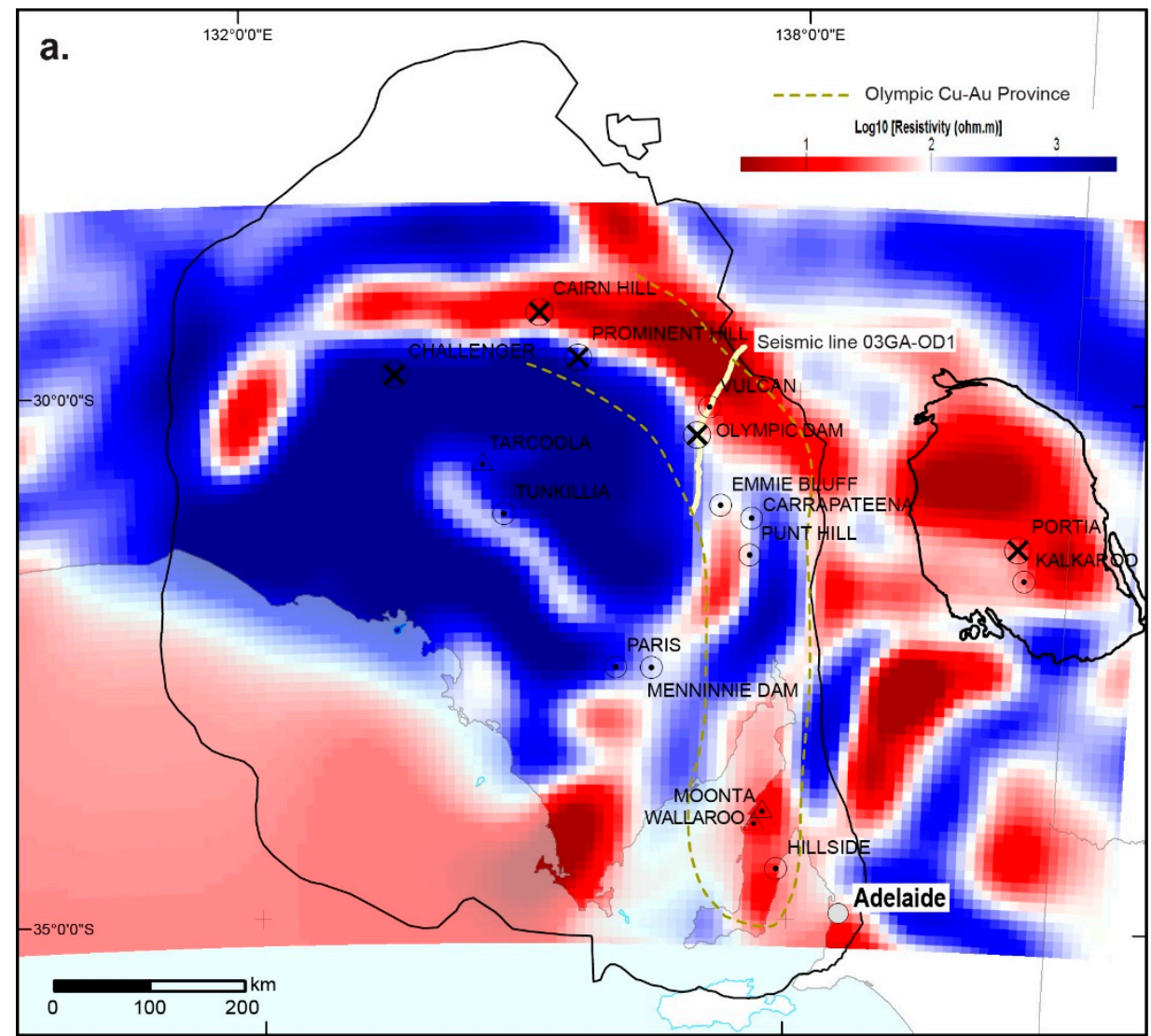

b.

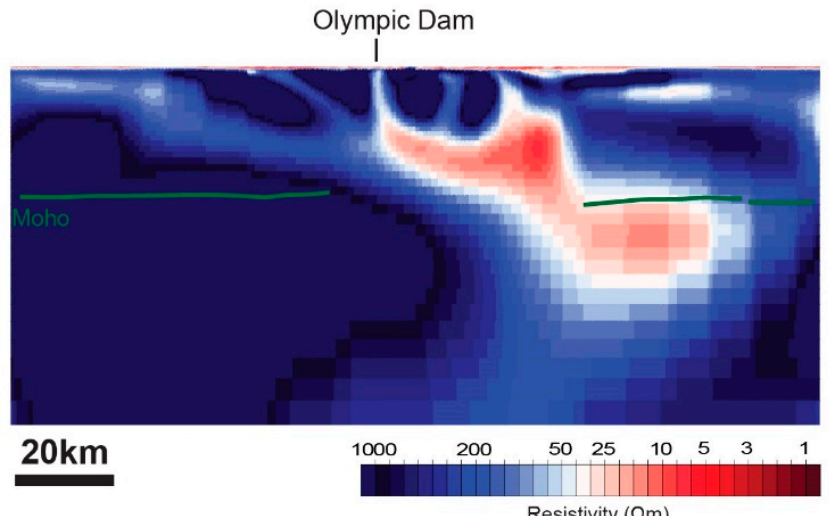

Figure 5. Resistivity model across the Gawler Craton and Curnamona Province. (a) Resistivity model at $55 \mathrm{~km}$ depth derived from AusLAMP magnetotelluric data [101]. (b) Resistivity model from detailed magnetotelluric sample sites at $1 \mathrm{~km}$ spacing parallel to seismic line 03GA-OD1. Modified from [93].

\section{Geodynamic Setting of the Olympic Cu-Au Province}

The mineralisation process across the Olympic $\mathrm{Cu}-\mathrm{Au}$ Province was linked to widespread magmatism, metamorphism and deformation across the Gawler Craton and Curnamona Province during the Kararan and Olarian orogenies over the broad time interval ca. 1610-1575 Ma. The geodynamic drivers for these events are poorly constrained. The association between extensive bimodal A-type magmatism, high-temperature metamorphism, and localized compressional deformation, is suggestive of an intracontinental setting for this time period in the Gawler Craton and Curnamona Province [70]. Indeed, many models for the geodynamics of these events emphasize mantle underplating or mantle plume activity as a key mechanism $[52,54,96,102]$. In these models, a mantle plume underplate the base of the lithosphere causing intrusion of mafic magmas into the lower crust resulting in extensive crustal melting. 
Recognition of both compressional deformation and high temperature metamorphism associated with this magmatic event in the Gawler Craton and Curnamona Province has led to other models that invoke switches in tectonic mode from compression to extension driven by far-field subduction zones (e.g., [30-32]). Therefore, in many reconstructions the Gawler Craton and Curnamona Province are placed in a continental back arc setting in which continental crust is considered to be mechanically connected to a nearby subduction system. For example, Wade, et al. [103] interpreted ca. 1640-1550 Ma magmatic rocks in the Musgrave Province to have 'arc-like' affinities. In their model, the Gawler Craton was placed distal to this arc, and inferred back arc extension linked to subduction dynamics at this northern margin could have been responsible for asthenospheric upwelling beneath the Gawler Craton leading to the voluminous magmatic events associated with the Hiltaba Suite and Gawler Range Volcanics (Figure 6a).

\section{a. Wade et al 2006}

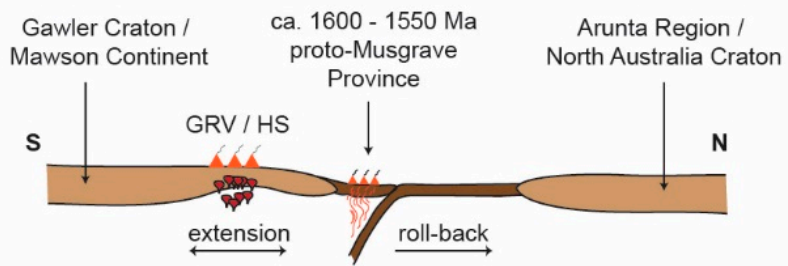

\section{b. Betts et al 2009}
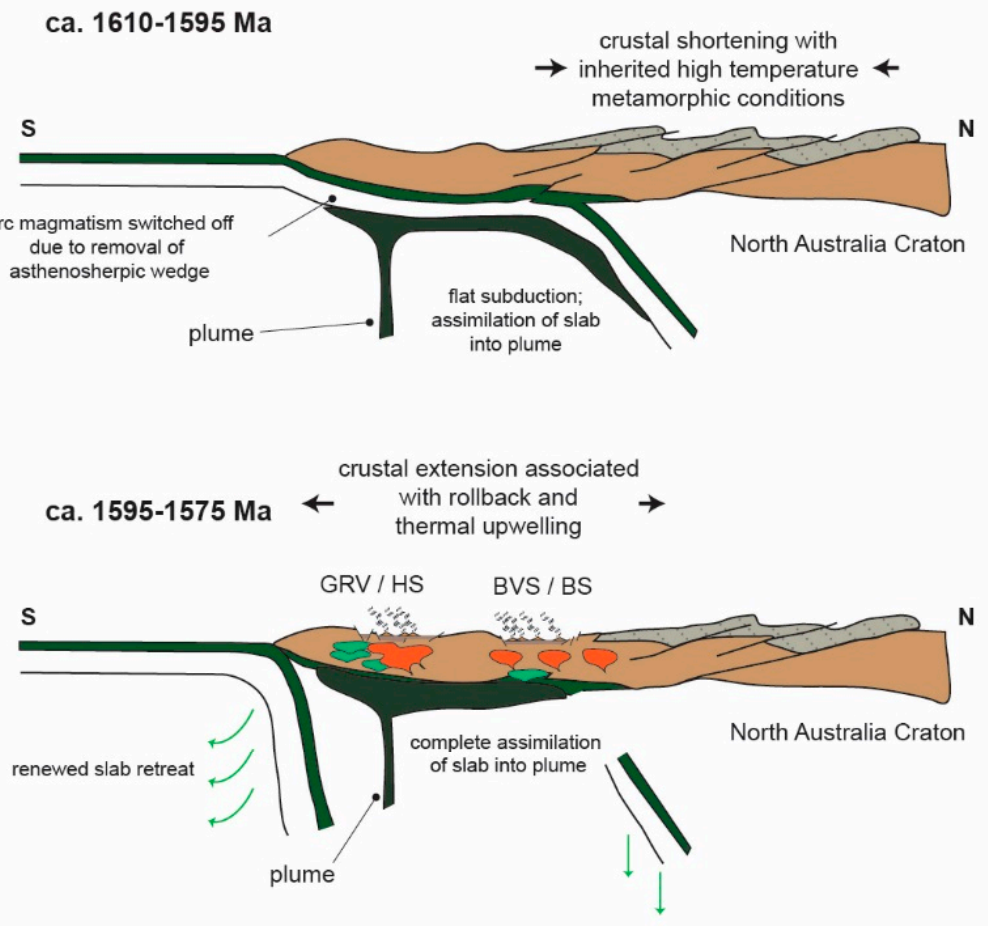

Figure 6. Cont. 


\section{Skirrow et al 2018}

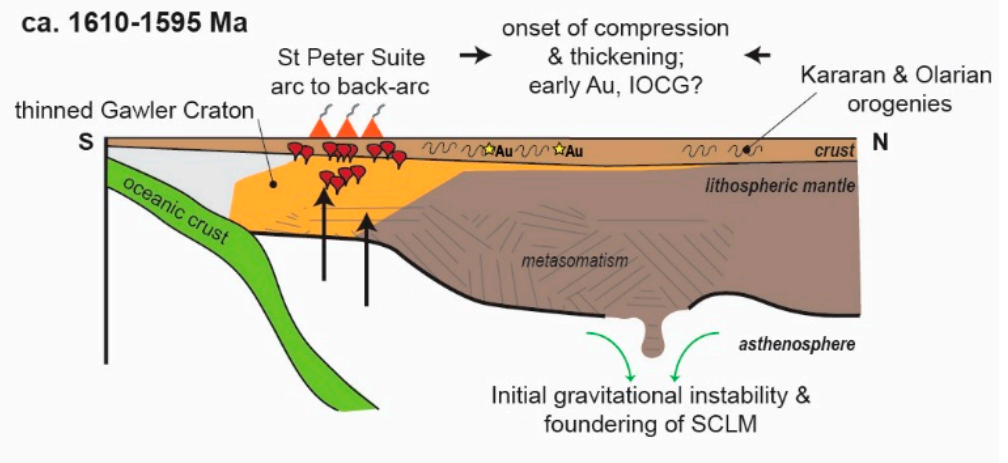

ca. 1595-1575 Ma

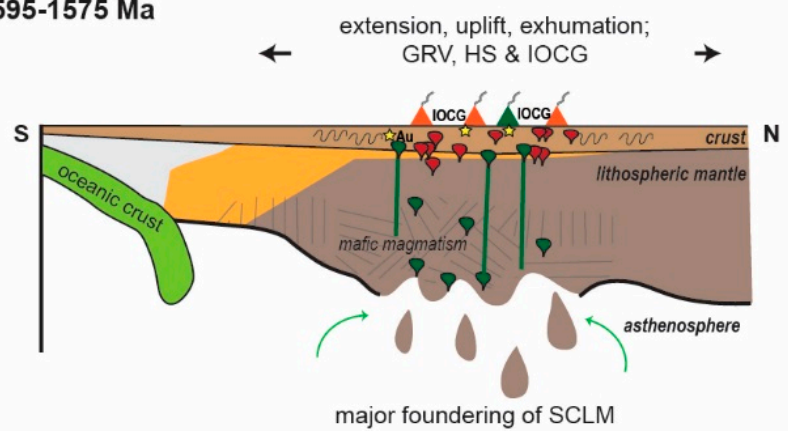

Figure 6. Examples of models for the tectonic setting of the Gawler Range Volcanics and Hiltaba Suite magmatism in the Gawler Craton and associated mineralisation in the Olympic Cu-Au Province. In each image, the current north is to the right of the diagram. Abbreviations used: GRV-Gawler Range Volcanics; HS-Hiltaba Suite; BVS-Benagerie Volcanic Suite; BS-Bimbowrie Suite. (a) Model of Wade, et al. [103] in which subduction to the north of the Gawler Craton (and broader Mawson Continent) recorded in arc-like magmatism of the Musgrave Province results in back-arc extension in the Gawler Craton. This extension produced high heat flow and associated magmatism. (b) Model of Betts, et al. [104] in which subduction zone dipping northwards beneath the Gawler Craton is interpreted to have interacted with a mantle plume. The combination produces high heat flow and tectonic switches from compression to extension that characterize the geological record from the region. (c) Model of Skirrow, et al. [32] in which northwards dipping subduction beneath the Gawler Craton resulted in metasomatism of the subcontinental lithospheric mantle. This is followed by delamination of gravitationally unstable regions leading to widespread mantle and crustal melting and hence formation of the Gawler Range Volcanics and Hiltaba Suite.

Betts, et al. [104] also propose a relationship between subduction and magmatism. In their model, they identify the ca. 1620 Ma St Peter Suite as being indicative of a subduction zone having existed to the south-west of the Gawler Craton (Figure 6b). Betts, et al. [104] suggest that the interaction of this subduction zone and a mantle plume caused tearing of the down-going slab and a switch in tectonic mode from compression to extension in the overriding plate. In this model, the result of these geodynamic processes was the extensive mantle and crustal melting in the Gawler Craton and Curnamona Province over the interval 1595-1575 Ma.

A continental back-arc setting for the Hiltaba Suite-Gawler Range Volcanics magmatism was also invoked by Skirrow, et al. [32] (Figure 6c). In this model the juvenile magmatism of the ca. $1620 \mathrm{Ma}$ St Peter Suite is cited as a key piece of evidence for subduction prior to the Hiltaba Suite-Gawler Range Volcanics magmatic event. In addition, the model suggests subduction was linked to a process of foundering, or delamination of the sub-continental lithospheric mantle beneath the Gawler Craton. Skirrow, et al. [32] argue that delamination driven by gravitational instabilities of the metasomatized, 
eclogitic root beneath the Gawler Craton provides a means to deliver high heat flow to the base of the crust and drive extensive crustal melting (Figure 6c).

At the global scale, the Gawler Craton and Curnamona Province were part of the Mawson Continent, which was part of the Nuna supercontinent during the Mesoproterozoic (e.g., [105,106]). Pehrsson, et al. [40] demonstrated that amalgamation of Nuna over the period ca. $2200 \mathrm{Ma}$ and $1780 \mathrm{Ma}$ is dominated by interior-type, oceanic closure orogenesis and related magmatism and metallogeny. A subsequent switch to more exterior-type, extensional dominated orogenesis during the protracted break-up phase of Nuna is a global phenomenon, likely a significant factor in the transfer of metals and fluids from the fertile subcontinental lithospheric mantle into the upper crust [40]. IOCG and unconformity-related uranium deposits are more common in such tectonic settings. Examples of IOCG-related mineralisation districts include the Olympic Cu-Au Province, Mt Isa Terrane and the Wernecke Supergroup. Examples of unconformity-related uranium deposits are the Athabasca and Kombolgie districts. Therefore, descriptions of IOCG mineral systems being localized into back arc, intracontinental settings such as that given by Groves, et al. [3] are consistent with the geodynamic setting inferred by many authors for the Olympic $\mathrm{Cu}-\mathrm{Au}$ Province.

Regardless of the specific geodynamic setting that has been proposed for the Olympic $\mathrm{Cu}-\mathrm{Au}$ Province and the broader Gawler Craton-Curnamona Province at the beginning of the Mesoproterozoic, the key parts of the geodynamic system that have been consistently identified are:

- Metasomatized subcontinental lithospheric mantle beneath the Gawler Craton in general, and the eastern Gawler Craton in particular [26,32,96];

- High-temperature igneous intrusion as manifest by the Hiltaba Suite and related bimodal Gawler Range Volcanics and Benagerie Volcanic Suite [53,70,107,108];

- Synchronous deformation activity that was largely focused along the margins of the Gawler Craton and Curnamona Province in regions such as Yorke Peninsula [56], northern Gawler Craton $[55,109]$ and the southern Curnamona Province such as around the Broken Hill district (e.g., [71,72,110]);

- The presence of volcano-sedimentary depocentres associated with volcanic activity [111,112];

- The pre-Mesoproterozoic crustal architecture of the Gawler Craton which was such that the region of the Olympic $\mathrm{Cu}-\mathrm{Au}$ Province had largely escaped earlier high-temperature metamorphic and deformation events [64].

In combination, these factors appear to have primed the mantle and crust for the IOCG mineralisation event. A metasomatized mantle appears to have been significant as it was both able to melt preferentially and to also potentially carry metals into the crust [26]. Metasomatism and subsequent plume activity has been discussed in the context of Au-rich metallogenic provinces [113], and it is likely that similar enrichment processes were active in the Olympic $\mathrm{Cu}$-Au Province. In addition, the presence of fluorine in the metasomatized mantle source region and in magmatic rocks derived from this mantle source was likely highly important for both viscosity of silicic magmas $[53,114]$ and also for the metal carrying capacity of hydrothermal fluids derived from these magmas [115]. The heat transfer from mantle to the crust as a result of extensive mafic intrusion resulted in both felsic magmatism by fractional crystallization from mafic sources, but also to widespread crustal melting and magma derivation [52]. Magmatic-derived fluids are indicated as sources of at least some components of the IOCG mineralizing system (e.g., [116,117]).

In the eastern Gawler Craton the upper crust was dominated by volcano-sedimentary successions of the Wallaroo Group. This succession includes clastic and chemical sediments such as carbonates, together with mafic and felsic volcanics [118]. This type of lithological association can reasonably be expected to be reactive during emplacement of magmas and related fluid systems and to also have carried their own fluid and metal inventory [64]. Furthermore, the presence of rare scapolite suggests a possible evaporitic component within the Wallaroo Group, which may have been significant in providing a source for some high salinity fluids [119]. 
Deposition of huge volumes of volcanic rocks in the Gawler Range Volcanics and Benagerie Volcanics was localized by regional fault systems interacting with the pre-existing surface topography. Sedimentary basins also developed in association with these fault systems [112,120] and these upper crustal, fluvial to lacustrine deposits are implicated in the fluid mixing models for high-level hematite-dominant IOCG deposits such as Olympic Dam [111]. The broadly synchronous deformation activity recorded in the Kararan and Olarian orogenies could have been significant in setting up the fault architecture being a driver critical in the location of subsequent IOCG deposits. Indeed, the localization of the Olympic Dam deposit into a pre-existing Hiltaba Suite granite requires a structural control on the localization of the hydrothermal system [31].

\section{Mineral and Chemical Footprints of Fluid Flow in the Olympic Cu-Au Province}

\subsection{Alteration Mineralogy and Mineral Assemblages}

In common with many highly endowed metallogenic provinces across the world, alteration minerals are a near ubiquitous feature of the geology of the Olympic $\mathrm{Cu}$-Au Province. The regional scale of the alteration mineralogy present across the eastern Gawler Craton attests to the large extent of the hydrothermal fluid system established during this event. Alteration minerals commonly encountered include chlorite, white mica, K-feldspar, albite, amphibole, biotite, garnet, pyroxene, carbonate, sulphides, magnetite and hematite. While there is quite a range of alteration minerals, they form relatively coherent groupings or alteration assemblages, related to the evolution of fluids that predominantly reflect fluid temperature and the composition of the protolith. Key papers that discuss the alteration systematics include Gow, et al. [117], Skirrow, et al. [21], Bastrakov, et al. [116] and Conor, et al. [119]. These, together with the work of Montreuil, et al. [121] and Corriveau, et al. [19] on alteration facies in IOCG systems in the Great Bear Zone of western Canada provide a framework within which to understand the mineralogical composition of alteration systems of the Olympic $\mathrm{Cu}-\mathrm{Au}$ Province. These alteration mineral assemblages can be used as part of an integrated petrological and geophysical approach to mineral exploration targeting (e.g., [27,122,123]).

Skirrow, et al. [124] and Skirrow, et al. [21] recognize four main alteration assemblages across the Olympic $\mathrm{Cu}$-Au Province. The first comprises magnetite-albite plus calc-silicate minerals such as actinolite and or clinopyroxene along with quartz, pyrite, apatite, titanite, chalcopyrite, pyrrhotite, scapolite and allanite (Figure 7a,b). This alteration is abundant in the Moonta-Wallaroo and Mt Woods districts. The second alteration assemblage is predominantly found in metasedimentary rocks of the Moonta-Wallaroo and Mt Woods regions and is dominated by magnetite-biotite (Figure 7c,d) or magnetite-amphibole and often associated with pyrite, chalcopyrite, albite, apatite, monazite and tourmaline. The third alteration assemblage is K-feldspar-dominant, and includes abundant K-feldspar together with magnetite and earlier formed calc-silicate minerals (Figure 7e). This K-feldspar alteration may completely replace earlier formed albite in the Olympic Dam district [116] or occur as locally dominant zones in the Moont-Wallaroo and Mt Woods regions [23,119]. The K-feldspar alteration is also associated with amphibole, titanite, chlorite and biotite (Figure $7 \mathrm{f}$ ) and may also be associated with sulphides including pyrite, chalcopyrite and pyrrhotite.

In addition to these iron oxide-dominant alteration assemblages, there are also skarn alteration assemblages in some regions of the Olympic $\mathrm{Cu}-\mathrm{Au}$ Province, in particular the region around the Punt Hill prospect and the Hillside deposit $[23,119,125]$. In these examples, typical prograde skarn assemblage predominantly composed of garnet and pyroxene are overprinted by a retrograde assemblage of amphibole, calcite, talc, chlorite, K-feldspar, hematite, fluorite, apatite, barite, anhydrite, epidote, tourmaline and titanite (Figure 8a-d) $[23,123,125]$. Sulphides including chalcocite, bornite, chalcopyrite, sphalerite, galena, pyrite along with native gold are also described from the region [123]. Garnet in these systems is predominantly Ca-Fe-rich andradite and grossular and occurs in both prograde and retrograde skarn alteration assemblages, although the REE signature changes from a heavy REE-dominant prograde skarn to light-REE-enriched retrograde skarn [23]. Significantly, skarn 
alteration assemblages are in places overprinted by hematite, sericite, chlorite and sulphides. Skarn alteration across the Olympic Cu-Au Province is predominantly related to high temperature fluids interacting with probable calcareous protoliths of the Wallaroo Group.
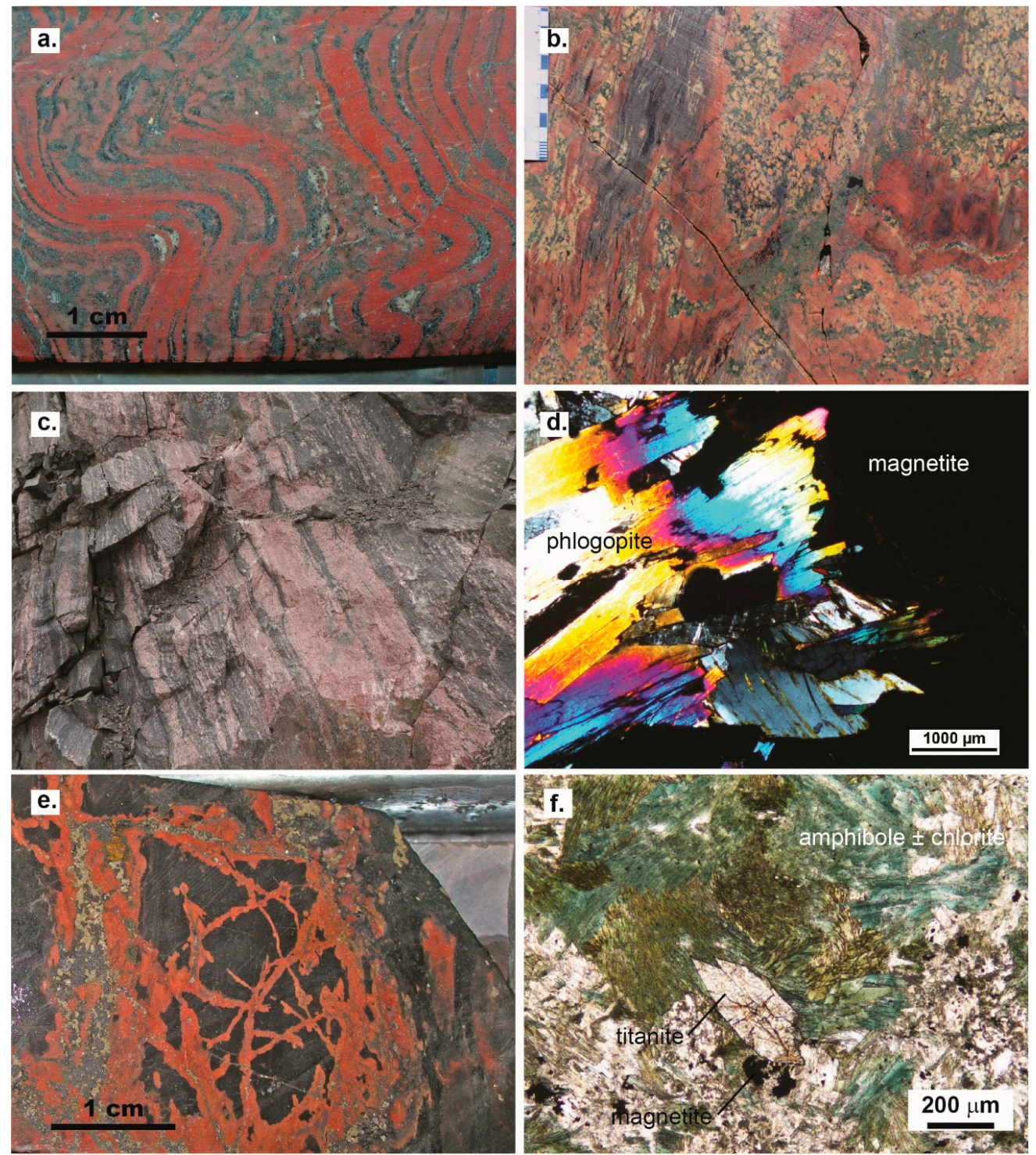

Figure 7. Examples of albite and magnetite-rich alteration assemblages from the Olympic $\mathrm{Cu}-\mathrm{Au}$ Province. (a) Laminated albite-calc-silicate metasomatite, drill hole St Joe PB 12, $130 \mathrm{~m}$. Fine layering suggests the protolith was metasedimentary. Albite is hematite-dusted and is red in colour. (b) Oorlano Metasomatite from near Wallaroo, Yorke Peninsula. Mineralogy includes albite, microcline, actinolite, magnetite and quartz, with the green coloured zones being richer in diopside, amphibole, epidote and magnetite, along with titanite, pyrite, apatite and hematite. Scapolite may also be present and magnetite is greater in abundance than hematite. (c) Magnetite-amphibole alteration at the Cairn Hill Fe-Cu deposit, Mount Woods district. Magnetite-amphibole \pm biotite overprints granite gneiss and occurs parallel to the main tectonic foliation [126]. Field of view approximately $3 \mathrm{~m}$ wide. (d) Thin section photomicrograph of phlogopite-magnetite assemblage from Cairn Hill. Sample 1998157 from magnetite ore. (e) K-feldspar-hematite veins cross-cutting siltstone. Veining is associated with pyrite-chalcopyrite and very fine-grained white mica + hematite alteration. Drill hole MALD 1, 131 m, Yorke Peninsula region. (f) Thin section photomicrograph of amphibole-chlorite-titanite alteration. Sample 1,833,361, drill hole AD8, 842.1 to $842.2 \mathrm{~m}$. 

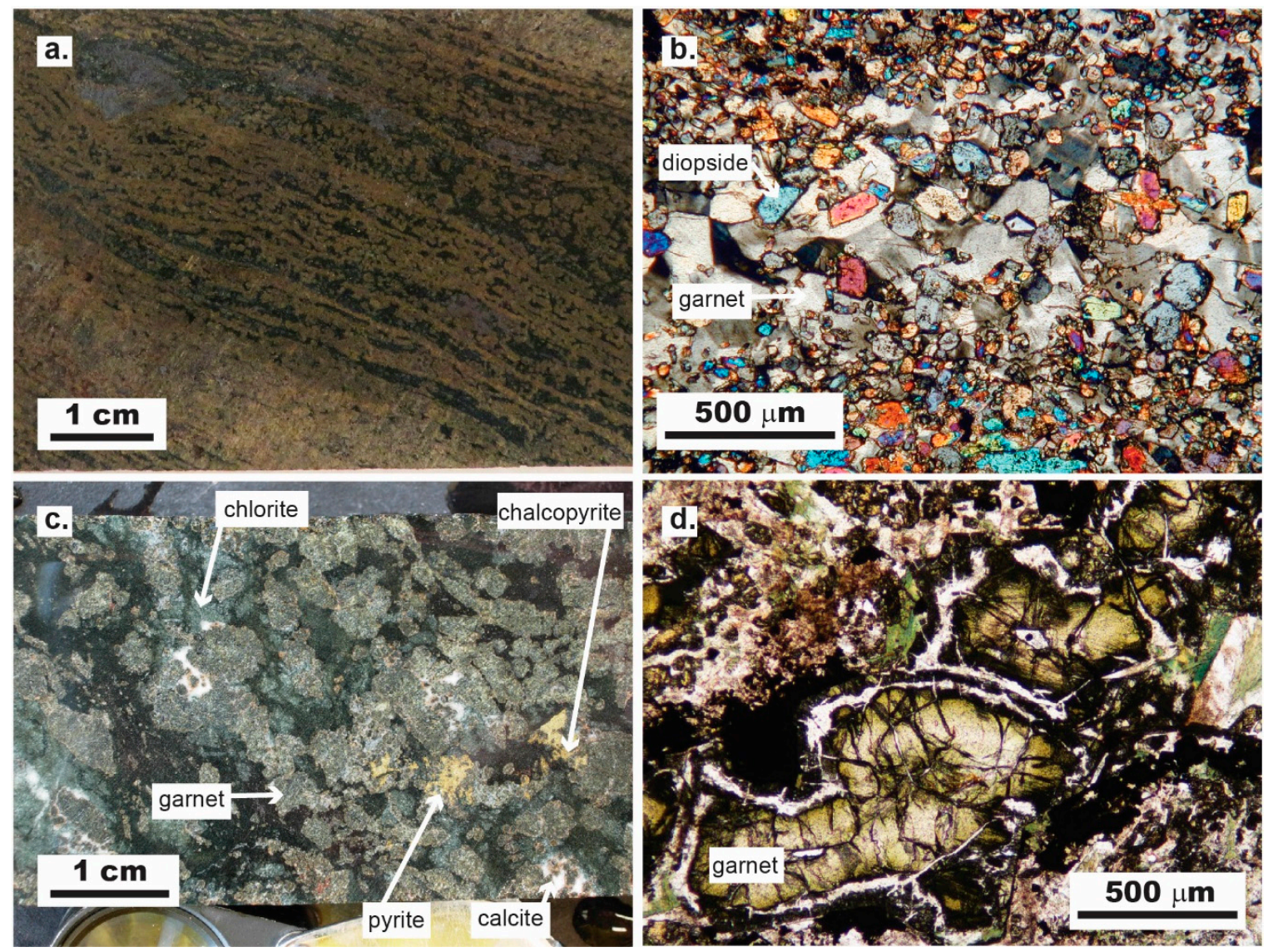

Figure 8. Examples of skarn alteration assemblages from the Olympic $\mathrm{Cu}$-Au Province. (a) Typical fine to medium grained banded skarn alteration. Drill hole HODD3, $1094 \mathrm{~m}$. (b) Thin section scale view of banded skarn showing garnet (light grey to black) intergrown with pyroxene (diopside). Sample 1,709,149, drill hole PD DD2, $991.1 \mathrm{~m}$. (c) Example of coarse grained, retrograde skarn assemblage comprising garnet, pyroxene, calcite, chlorite and amphibole (dark green zones). Note pyrite and chalcopyrite in this phase of skarn alteration. (d) Thin section view of retrograde skarn showing green coloured, compositionally zoned andradite garnet intergrown with white calcite and dark hematite. Green mineral is chlorite and matrix contains very fine grained quartz-sericite-hematite intergrowth. Sample 1,833,364, drill hole DDH AD8, $861 \mathrm{~m}$.

The fourth alteration assemblage defined by Skirrow, et al. [21] is dominated by hematite-sericite-chlorite (Figure 9a,b) and is associated with carbonate, pyrite, chalcopyrite, bornite, chalcocite along with barite, fluorite, apatite, uranium and rare earth element (REE) minerals $[20,117,127-129]$. This hematite-rich alteration is most commonly manifest as complex breccia systems in which brecciation and hematite-sericite-chlorite alteration are synchronous and multiphase. Hematite-breccias commonly containing more than $50 \%$ iron oxide are present at the Olympic Dam, Prominent Hill and Carrapateena deposits and are widespread across the region at numerous prospects such as Vulcan (Figure 9c-f). Importantly, hematite often is a pseudomoph after magnetite (Figure 9e,f), indicating a change in redox state of the main iron oxide component, potentially during the interaction with oxidized fluids [117]. 

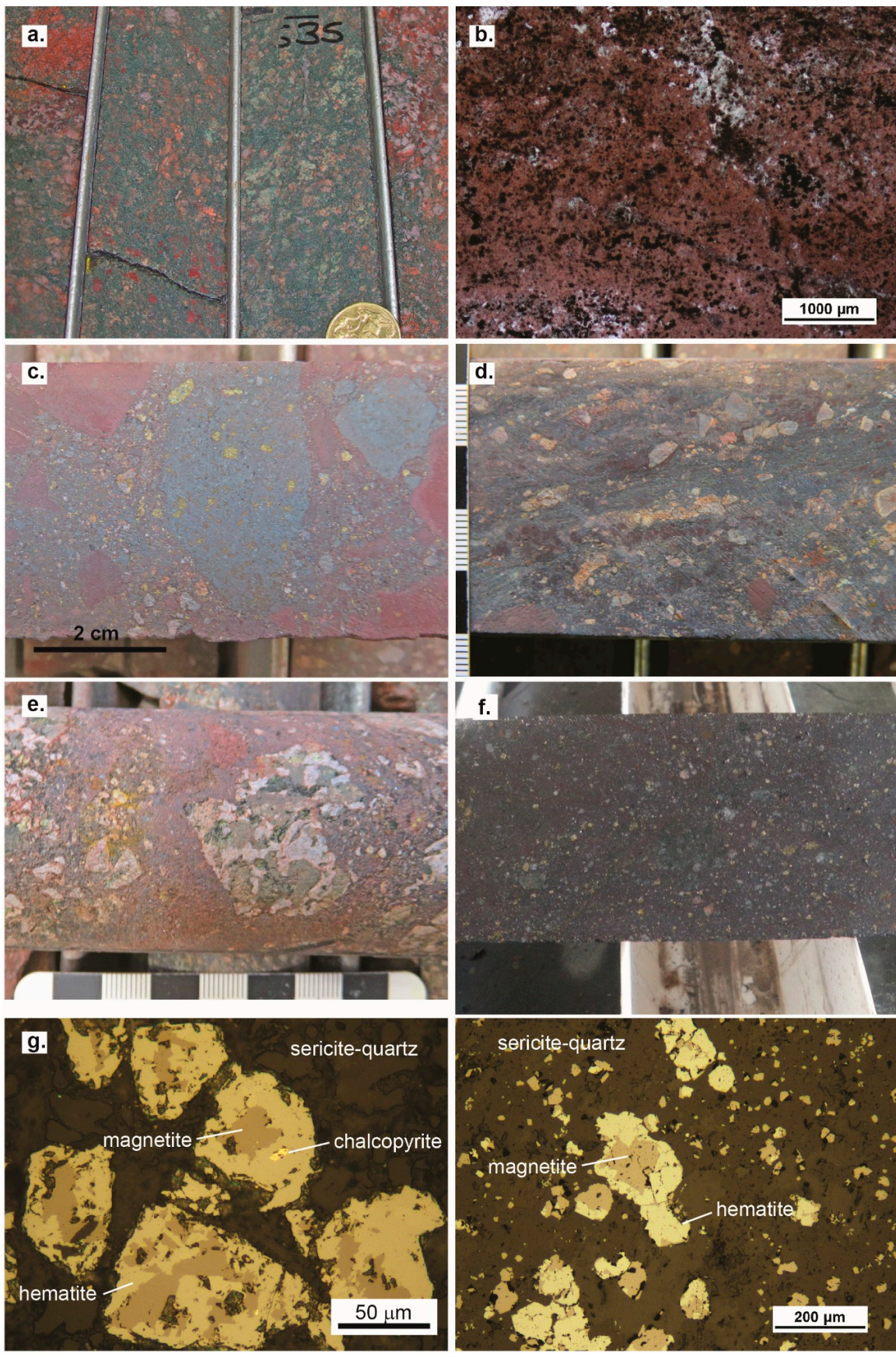

Figure 9. Examples of hematite-sericite-chlorite alteration styles and hematite breccia from the Olympic Cu-Au Province. (a) Chlorite-sericite-altered granite, drill hole MGD 34, 535 m. Granite is 1850 Ma Donington Suite. (b) Fine-grained sericite-chlorite-hematite alteration. Emmie Bluff prospect, sample 1,833,355, drill hole SAE 7966.5 m. (c) Hematite breccia from Olympic Dam. Underground drill hole RU39. Note multi-phase brecciation, with clasts of hematite breccia within the hematite breccia matrix. (d) Hematite breccia from Prominent Hill discovery hole, Uran 1. (e) Clast of chlorite-sericite-altered granite (1850 Ma, Donington Suite) within hematite breccia, Carrapateena deposit. Drill hole CAR02, $585 \mathrm{~m}$. (f) Fine-grained hematite breccia with minor sulfides, Vulcan prospect. Drill hole RCDD11VUD007, $1138 \mathrm{~m}$ [130]. Drill core $\sim 5 \mathrm{~cm}$ wide. (g) Thin section photomicrograph showing relict magnetite cores within hematite. Note pyrite in one of the hematite pseudomorphs. Sample 1838226, drill hole RCDD11VUD007, 1202.3 m. h. A second example of relict magnetite cores within hematite. Emmie Bluff prospect, sample 1,833,355, drill hole SAE $7966.5 \mathrm{~m}$. 
The spectrum of alteration assemblages can be resolved into groupings that represent the changing fluid conditions at which they form (Figure 10). Albite represents the highest temperature endmember, and typically forms very early in the mineral paragenesis. Widespread albite alteration is a common feature of the Olympic Cu-Au Province as well as the Curnamona Province [21,27,74,131], and is also a feature of alteration assemblages in Mt Isa and Great Bear districts [8,19]. This early sodic alteration is an important stage that can influence subsequent alteration as a result of changes in rock volume and porosity and due to the fluxing of other rock components such as magnesium and other metals, including copper and gold $[2,8,19,131]$.

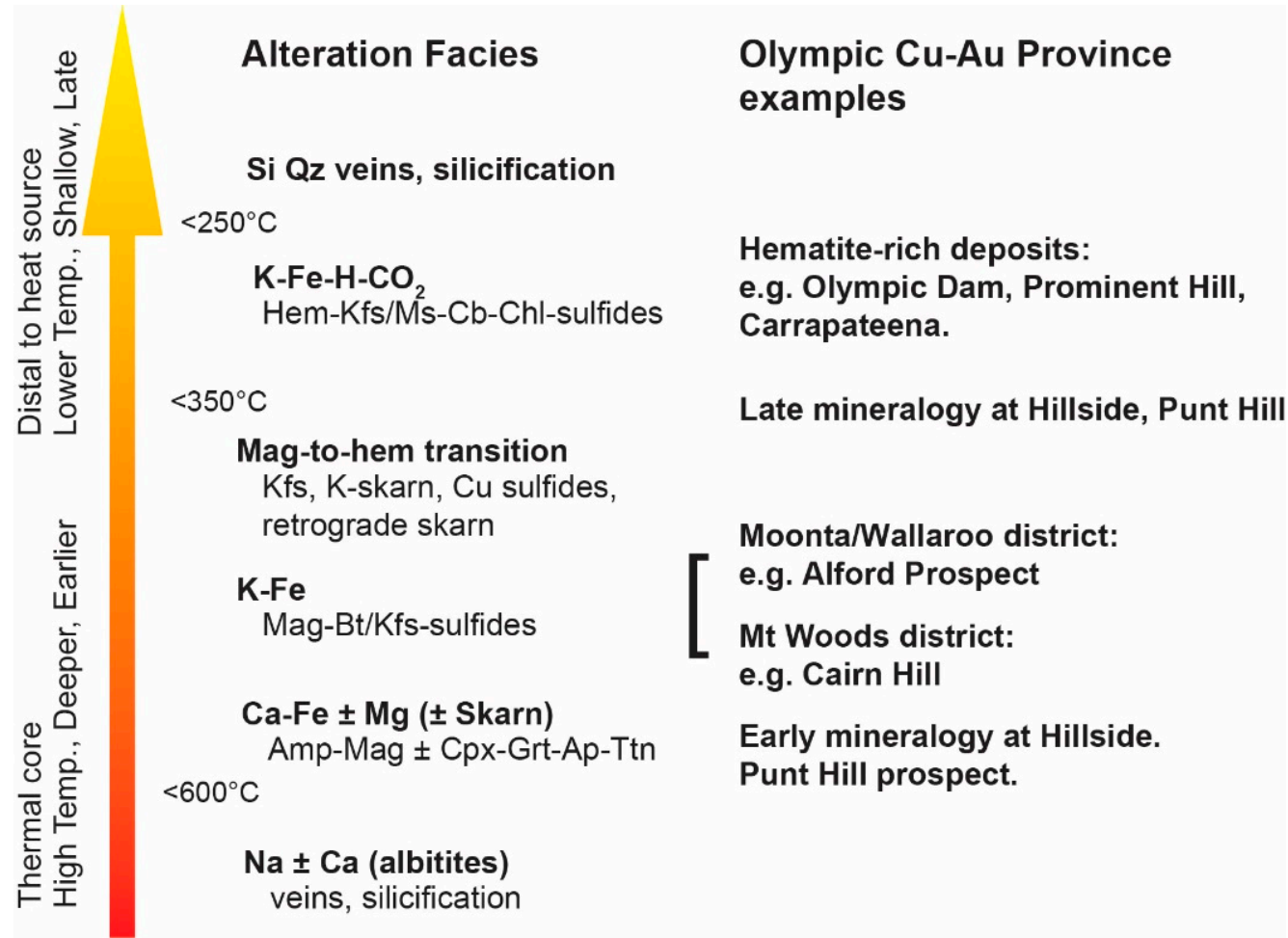

Figure 10. Iron oxide-copper-gold (IOCG) alteration facies model modified from Corriveau, et al. [19], with examples of deposits and prospects from the Olympic $\mathrm{Cu}$-Au Province that preserve similar alteration facies. This model systematizes the alteration mineral assemblages that form across the range of temperatures that produce IOCG systems. While some systems may evolve through the full temperature spectrum, other systems may preserve only high or low temperature portions of the hydrothermal fluid system. Mineral abbreviations are: Amp-amphibole, Ap-apatite, Bt—biotite, $\mathrm{Cb}$-carbonate, $\mathrm{Cpx}$ —clinopyroxene, Grt—garnet, Hem—hematite, Kfs-K-feldspar, Mag-magnetite, Ms-muscovite, Ttn-titanite.

A key observation from a recent deep drill hole beneath the Olympic Dam deposit is that beneath the hematite-breccia systems of Olympic Dam is magnetite and apatite-rich alteration within the host Hiltaba Suite granite [28]. This demonstrates that the earlier magnetite-alteration is spatially associated with the hematite-dominant IOCG systems. In some examples, the magnetite-rich alteration itself contains $\mathrm{Cu}$ and $\mathrm{Au}$ and has been a source of ore at the Cairn Hill deposit [132].

At the Hillside deposit, geothermometry from $\mathrm{Zr}$-in-titanite suggests temperatures around $600{ }^{\circ} \mathrm{C}$ for prograde hydrothermal fluids within skarn alteration, which is indicative of a magmatic fluid source [23]. Likewise, the spatial correlation between distal and proximal skarn assemblages based on garnet-pyroxene ratios in the Punt Hill region, suggest hydrothermal fluids could have emanated from large granitic bodies that intrude below Wallaroo Group metasedimentary rocks [123]. Analysis of fluid inclusions suggest fluids associated with magnetite alteration were hypersaline and $\mathrm{CO}_{2}$-bearing, however they typically have low sulphur and moderate copper concentrations [116]. Therefore it 
appears that early magnetite-rich and skarn alteration assemblages derived from a higher temperature, likely magmatic source [116].

In large regions of the Olympic $\mathrm{Cu}-\mathrm{Au}$ Province magnetite-rich alteration is overprinted by hematite-rich alteration assemblages $[20,25,130,133]$. Oxygen isotope studies from the Olympic Dam deposit implicate mixing of low temperature, meteoric fluids and higher temperature magmatic waters $[134,135]$. Fluid inclusions also suggest oxidized, lower temperature (200 to $\left.300{ }^{\circ} \mathrm{C}\right) \mathrm{SO}_{4}$-rich brines were responsible for the hematite overprint [116]. This is consistent with a two fluid model for the formation of the hematite-rich IOCG endmember deposits, in which a second phase of sulphur-rich, oxidized fluids reacted with the early magnetite-bearing assemblage to produce hematite plus copper sulphides [116,117]. Indeed, the early formed magnetite likely formed an important reactant with any secondary oxidized fluids and may be a key ingredient in the localization of subsequent copper mineralisation [116].

An important outcome of this summary of the alteration assemblages is the recognition that the full spectrum of alteration types associated with IOCG systems are present in the Olympic $\mathrm{Cu}-\mathrm{Au}$ Province. In this respect, there are similarities between the alteration styles and fluid evolution of the Olympic $\mathrm{Cu}-\mathrm{Au}$ Province and districts such as the Great Bear magmatic zone, Canada. In the Great Bear district progressive evolution of magmatic-derived fluids formed early albite-rich and magnetite-rich alteration to hematite-bearing potassic-iron, or epidote-bearing calcic or magnesian alteration [136]. Importantly, as in the Great Bear examples, the Olympic $\mathrm{Cu}-\mathrm{Au}$ Province demonstrates juxtaposition of different alteration facies, for example the hematite-rich alteration overprinting skarn assemblages in the example of Hillside deposit [119]. Key mechanisms for this type of overprinting include progressive fluid evolution through fluid-rock interaction, but also as a result of rapid tectonic controls on fluid pressure and chemistry such as via uplift [see discussion in 31].

While there is overprinting of high- by low-temperature alteration facies within the individual deposits or prospects across the Olympic $\mathrm{Cu}$-Au Province, there remains a broad spatial clustering of the various alteration assemblages. For example, magnetite-dominant alteration is most common in the north and south of the Olympic $\mathrm{Cu}$-Au Province, as evidenced by the Cairn Hill deposit in the Mount Woods Domain and the Moonta-Wallaroo and Hillside deposits in the south [21,119]. In the Mt Woods Domain, high temperature metamorphism is recorded at broadly the same time as the timing of low temperature hematite-rich mineralization and alteration at deposits such as Olympic Dam. Similar mid-crustal deformation and metamorphism is also recorded in the Moonta-Wallaroo district of Yorke Peninsula [21,130]. In contrast, Olympic Dam and vicinity preserves hematite-rich sericite-chlorite alteration systems, for example the Acropolis, Vulcan and Wirrda Well prospects [129,130]. Prominent Hill preserves similar alteration and mineralisation being a hematite-dominated IOCG system and defines a northerly extent of the upper crustal IOCG systems of the Olympic $\mathrm{Cu}$-Au Province.

While there is this broad spatial clustering, it is critical to recognize that these spatial features are indicative of the paleo-erosion surface across the Olympic $\mathrm{Cu}$-Au Province. In this respect, the preservation of hematite-rich IOCG systems co-located with preserved upper crustal rocks such as the Gawler Range Volcanics indicates that erosion in such regions subsequent to mineralisation has been relatively limited. In contrast, the magnetite-rich IOCG systems likely represent a deeper crustal level that has been brought to the paleo-erosion surface by exhumation. This is most obvious in the Mt Woods Domain, where the Southern Overthrust has juxtaposed the mid-crustal rocks against upper crustal rocks to the south, the latter of which include the host rocks to the Prominent Hill deposit $[22,137,138]$. The confirmation of magnetite-bearing assemblages at depth beneath Olympic Dam [28,128] demonstrates the significance of post-mineralisation exhumation and erosion for understanding the alteration styles preserved in a given region. The deeper the exhumation, the more likely magnetite-rich alteration will be preserved rather than hematite-rich alteration. 
Mineralogical trends related to ore systems are influenced by protolith, whereby fluid interaction with metasedimentary rocks of the Wallaroo Group tend to display a much wider array of alteration mineralogy than granitic or felsic volcanic protoliths. At Olympic Dam, the host granite, the Roxby Downs Granite, is selectively and progressively altered towards the centre of the orebody (Figure 11). This alteration pattern is a useful guide for proximity to hematite-rich orebodies in the Olympic $\mathrm{Cu}-\mathrm{Au}$ Province. Hyperspectral imaging of drill core shows a general increase of sericite, chlorite and hematite towards the deposit, and that sericite and chlorite become progressively more Fe-rich towards the centre of the orebody [27]. Feldspars of the Roxby Downs Granite are also variably altered, such that igneous feldspar (perthite) is overprinted by albite (distal) and K-feldspar (proximal), igneous plagioclase becomes completely replaced by albite, sericite and Ba-rich K-feldspar [29], while igneous biotite is firstly replaced by chlorite around the orebody and completely destroyed within it [20]. Importantly, the degree of albite alteration increases away from the orebody, while towards the centre of the orebody, red-stained, Fe-rich K-feldspar is present, while sericite completely replaces all plagioclase $[27,29]$.

Alteration of Wallaroo Group metasedimentary rocks is more variable. Early, high temperature alteration dominated by albite, clinopyroxene and magnetite is typically replaced by K-feldspar-amphibole-magnetite and subsequent hematite-sericite-chlorite-carbonate alteration assemblages within mineralized zones. Within zones of mineralization, Fe-rich chlorite and sericite are abundant along with Fe oxide, typically hematite [139]. In skarn assemblages developed within and proximal to calcareous units of the Wallaroo Group, carbonate minerals are present distal to mineralization and plagioclase, K-feldspar and white mica are common. Proximal alteration and zones most strongly linked to $\mathrm{Cu}$ mineralization include retrogressed skarn mineralogy dominated by amphibole, chlorite, talc, epidote, K-feldspar as well as garnet and pyroxene [123].

\subsection{Chemical Trends}

Chemical gradients are also evident across the Olympic $\mathrm{Cu}$-Au Province that may reveal trends of fluid flow directions or proximity to ore deposits [138]. These include major element variations that map changes in feldspar composition (e.g., ratio of $\mathrm{Na}$ to $\mathrm{K}$ in whole rock geochemical data as a proxy for degree of alteration; $[139,140])$. Regional geochemical anomalism in elements including Bi, $\mathrm{Ag}$, As, $\mathrm{Cu}, \mathrm{Fe}, \mathrm{Sb}$, Se, $\mathrm{W}$ define distal chemical 'footprints' or envelopes across the Olympic $\mathrm{Cu}-\mathrm{Au}$ Province $[139,141]$. Elements such as Ce, La and Te are indicative of proximity to ore systems; values $>10 x$ typical crustal abundance for these elements to be a significant enough 'anomaly' to warrant attention [139].

In the regions where skarn alteration and mineralization is present, elements associated with $\mathrm{Cu}$ mineralization and related alteration zones include $\mathrm{As}, \mathrm{Bi}, \mathrm{Cd}, \mathrm{Mo}, \mathrm{Ni}, \mathrm{Pb}, \mathrm{Sb}, \mathrm{Se}, \mathrm{U}, \mathrm{W}, \mathrm{Zn} \pm \mathrm{Co}$ along with light REE. Pathfinder elements such as $\mathrm{As}, \mathrm{Bi}, \mathrm{Mo}, \mathrm{Sb}, \mathrm{W}$ have high values across the Punt Hill region; however, high $\mathrm{Sb}$ values have been found to be most strongly associated with alteration minerals and to therefore be a useful element for identifying kilometre-scale geochemical zones [123]. 


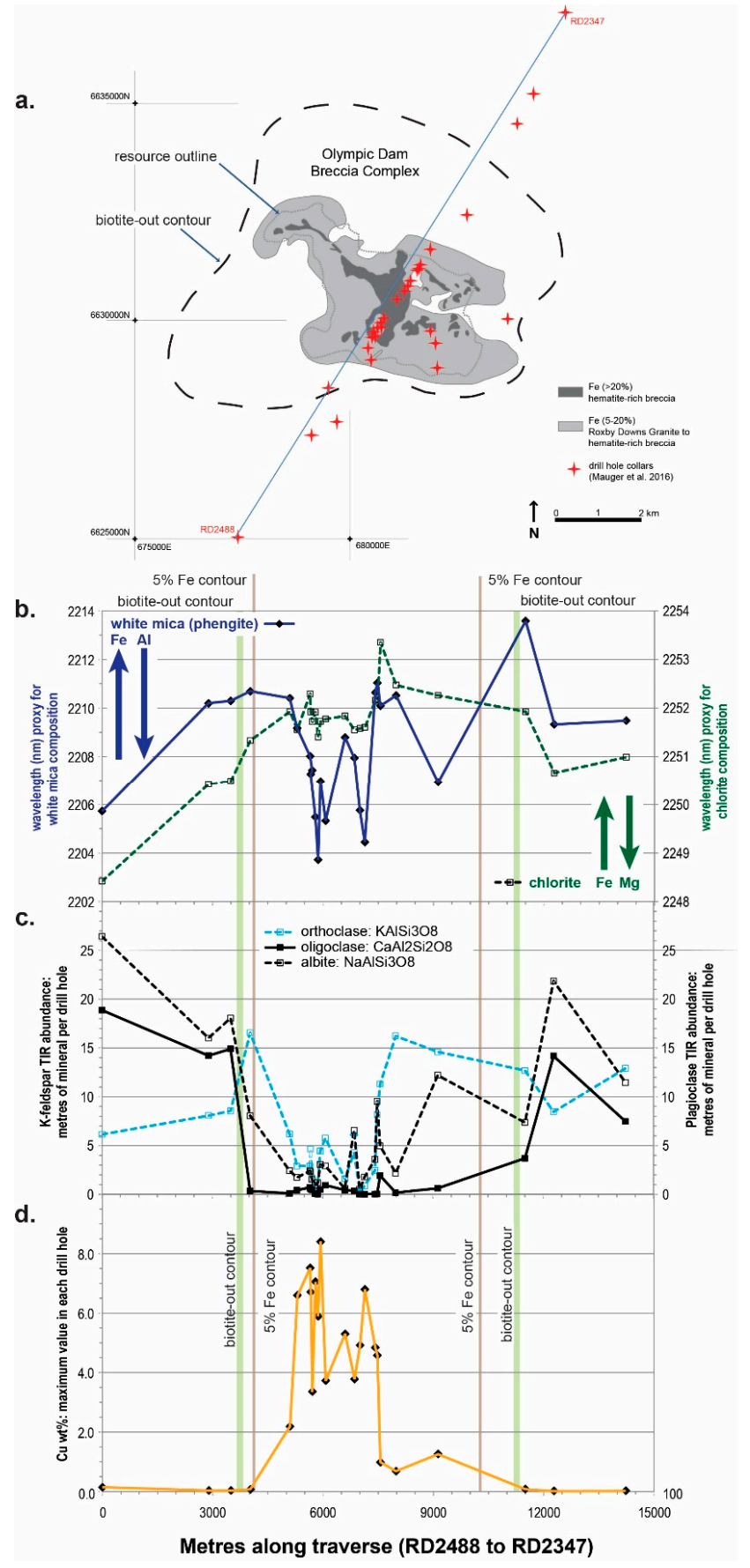

Figure 11. Summary of mineralogical trends across Olympic Dam. Modified from [20,27]. (a) Simplified outline of the Olympic Dam Breccia Complex within the Roxby Downs Granite showing the contour at which biotite is destroyed by progressive alteration (biotite-out contour), the 5-20\% Fe zone and the $>20 \%$ Fe zone. Also shown is the resource outline and drill holes analysed by HyloggerTM hyperspectral imaging [27]. (b) Cross section from drill hole RD2488 to RD2347 showing the wavelength of the characteristic absorption spectra from short-wave infrared imaging that characterizes white mica (phengite) and chlorite. Also indicated is the change in chemistry of the white mica and chlorite indicated by the changes in these absorption features. (c) Meters per drill hole of the K-feldspar and plagioclase abundance as measured by thermal infrared (TIR) imaging. Albite is greatest distal to the orebody, while orthoclase shows a slight increase towards the orebody. (d) Maximum values of $\mathrm{Cu}$ weight percent assays within each drill hole. The centre of the orebody is defined by the highest $\mathrm{Cu}$ values. 


\section{Cover Geology Across the Olympic Cu-Au Province}

The Olympic Cu-Au Province is buried beneath sediments of the Carriwerloo Basin as well as the Stuart Shelf, the latter part of the more extensive succession of the Adelaide Rift Complex (Figure 12). The Pandurra Formation was deposited in the Carriwerloo Basin and is preserved to the west of the Olympic Dam region. The thickness of the Pandurra Formation ranges up to one kilometre in some drill hole intersections, but may be more in some regions. The Pandurra Formation is a succession of relatively flat-lying continental redbed sedimentary rocks comprised of four units, a basal gritty sandstone rich in lithics; a shale and siltstone unit; a fine- to medium- grained sandstone; and a poorly sorted lithic sandstone. The Pandurra Formation onlaps the Gawler Craton along its western extent, while in the region around Olympic Dam the Pandurra Formation is largely fault bound and dissected by a number of vertical or near vertical fault systems. Recent work from the Olympic Dam deposit has shown that some sandstone blocks of Pandurra Formation are preserved within the deposit, indicating the current extent of the Pandurra Formation is a function of both preservation rather than marking the former extent of the Carriwerloo Basin [120]. Dating of shales by Rb-Sr and authigenic apatite by U-Pb suggests the Pandurra Formation was deposited ca. 1440 Ma [63,120]. The occurrence of broadly synchronous high-temperature metamorphism and granite emplacement in the northern Gawler Craton suggests the Carriwerloo Basin was related to a broader (extensional?) tectonic event at this time [60].

During the Neoproterozoic, extension across the eastern Gawler Craton resulted in extrusion of the Beda Basalt, intrusion of the Gairdner Dolerite and subsequent deposition of the Stuart Shelf platform sequences. The Beda Basalt comprises variably altered, amygdaloidal basalts and occur in a north-south trending sub-basin in the vicinity of Port Augusta (Figure 1). Although the Beda Basalt occupy a relatively small region, mafic magmatism of similar age is more extensive, as evidenced by the ubiquitous dyke swarms that constitute the ca. 820 Ma Gairdner Dolerite. The Gairdner Dolerite is evident on many regional aeromagnetic images and occurs in north-west trending series of dykes that reflect the onset of widespread extension across the Gawler Craton as Rodinia began to break up [142]. A succession of clastic sediments, the Backy Point Beds, were locally deposited associated with the Beda Volcanics.

During the Neoproterozoic sedimentation was widespread across much of southern and central Australia [76]. Deposition was focused into the Adelaide Rift Complex, where at least $14 \mathrm{~km}$ of sedimentary material accumulated in successive phases of rift evolution. The western margin of the Adelaide Rift Complex onlapped the Gawler Craton forming the Stuart Shelf. The main stratigraphic units of the Stuart Shelf are primarily the Umberatana Group with units including the Tapley Hill Formation, the Whyalla Sandstone, and lower Wilpena Group (Figure 12). In the northern Stuart Shelf region, around Olympic Dam, a succession of Cambrian limestones of the Hawker Group are preserved. The Tapley Hill Formation records the first marine transgression of the Stuart Shelf during the Neoproterozoic and consists of a transgressive-regressive sequence of mainly carbonaceous and dolomitic siltstones and shales. Finely laminated shales of the Tapley Hill Formation overly the Gawler Craton basement, although in many instances the unconformity surface locally characterized by a coarse-grained, sandy to conglomeratic siliciclastic unit, which in some areas contains base and precious metal mineralisation. Whole rock geochemistry of the basal unconformity sediments has been shown to preserve indicators of nearby basement-hosted copper mineralisation [139].

Thickness of the sedimentary cover across the eastern Gawler Craton increases from the regions of outcrop in the central Gawler Craton to very deep cover within the Torrens Hinge Zone (Figure 13). Around Olympic Dam the Neoproterozoic cover is around 300 to $440 \mathrm{~m}$, while Carrapateena lies beneath $\sim 470 \mathrm{~m}$ of cover. In the northern region, in the vicinity of Prominent Hill, the cover geology is dominated by Mesozoic continental sediments of the Eromanga Basin, which varies from 50 to $400 \mathrm{~m}$ in thickness. Recent work investigating the geochemistry of Mesozoic successions in the vicinity of Prominent Hill shows introduction of pathfinder elements into clay-rich horizons within the cover successions likely via upward migration from basement rocks [143]. The geochemical dispersion of 
economic and pathfinider elements into cover successions is therefore a potential source of information that can be applied towards understanding and targeting potential mineralization in the underlying crystalline basement.

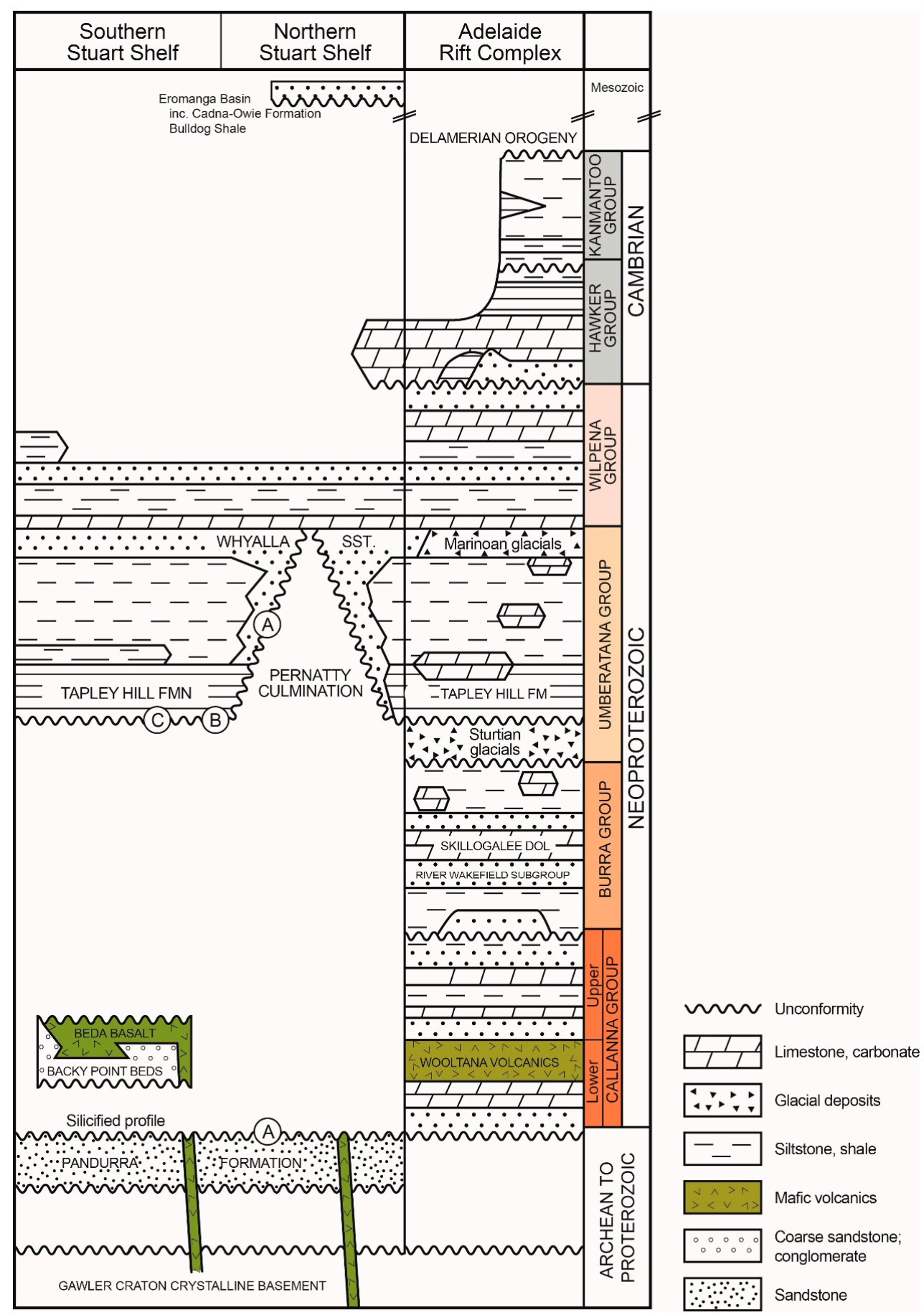

Figure 12. Summary stratigraphic column of cover units of the Stuart Shelf and Adelaide Rift Complex. Modified after $[77,144,145]$. The Southern Stuart Shelf refers to the region around the Moonta-Wallaroo region, also known as the Spencer Shelf. The Northern Stuart Shelf refers to the region around Olympic Dam. Letters A, B and C refer to the stratigraphic location of unconformity related copper mineralization at the Mount Gunson deposit, including the Cattle Grid (A) and MG14 (B) workings and the Myall Creek (C) deposit. Also indicated is the presence of Mesozoic successions of the Eromanga Basin in the northern portion of the Stuart Shelf region. 


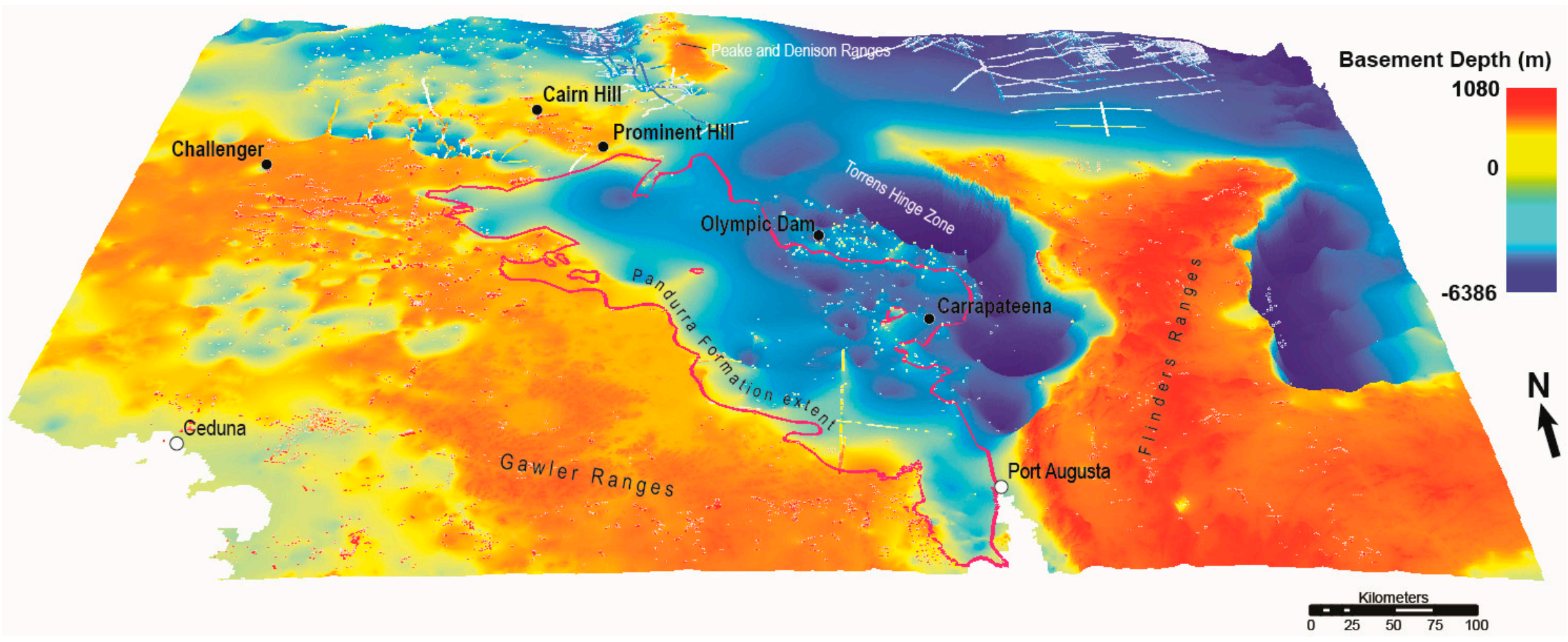

Figure 13. Basement depth model across Stuart Shelf region. Perspective view of interpreted basement geology surface across the central-northern portion of the Olympic $\mathrm{Cu}-\mathrm{Au}$ Province. Olympic Dam, Carrapateena and Prominent Hill mines are shown for location, as is the outline projected to the surface of the Pandurra Formation. Data sources for this basement depth model are given in Electronic Appendix 1 in Supplementary Materials and available via: https://sarigbasis.pir.sa.gov.au/WebtopEw/ws/samref/sarig1/wcir/Record?r=0\&m=1\&w=catno=2035148. 
The unconformity surface between the Gawler Craton basement and Pandurra Formation and Neoproterozoic sediments is in places mineralized, representing a distinct exploration target in its own right. Sandstone-hosted mineralization such as at the Mount Gunson deposit, is characterized by replacement of diageneitic and early syn-genetic pyrite in fractures and vugs at or near the silicified and brecciated paleosurface [144]. Diagenetic pyrite was also replaced by $\mathrm{Cu}-\mathrm{Fe}$ sulphides (chalcopyrite, bornite and chalcocite) within laminated mudstone-dolomite of the Tapley Hill Formation in deposits such as Myall Creek [77]. In both instances, mineralizing fluids were likely focused along regional structural breaks and culminations and deposited copper, and minor zinc and lead in chemically or structurally favourable sites, following the typical model for sedimentary-hosted copper systems [77].

\section{Discussion: Potential for Future Discovery}

Mineral deposits form as a result of the interaction of complex geological factors. These factors can be described in terms of a mineral system and used in predictive sense to determine the mineral potential of a region [34,36]. The key elements of a mineral system are:

(i) sources of ore metals, hydrothermal fluids and ligands

(ii) sources of energy to drive hydrothermal systems

(iii) structural pathways for fluid flow, and

(iv) physico-chemical boundaries or gradients along which ore metals are deposited (e.g., redox, pressure etc.)

Sources of ore metals and hydrothermal fluids in the IOCG mineral system of the eastern Gawler Craton includes the magmatic fluids related to the Hiltaba Suite and Gawler Range Volcanics. Crustal melting due to synchronous metamorphism could also provide a source of fluids and potentially ore metals, depending on the lithologies undergoing partial melting. In addition, sedimentary rocks in the mid- and upper-crust such as the Wallaroo Group may have provided both ore elements, for example $\mathrm{Cu}, \mathrm{Au}$ and $\mathrm{U}$ and also leached ligands such as $\mathrm{Cl}$ or $\mathrm{Na}$ from potential evaporate-bearing strata $[119,146]$. Locations in the eastern Gawler Craton where the Wallaroo Group sedimentary rocks were preserved are of higher potential as fluid sources than those regions to the west of the Gawler Craton in which the dominant rock types are of quartzo-feldspathic and of higher metamorphic grade [64].

The energy source for the mineral system was the tectono-metamorphic and related magmatic event that occurred across the Gawler Craton and Curnamona Province in the early Mesoproterozoic. The extensive magmatism associated with this event was the obvious heat source to drive fluid circulation in the mid- to upper-crust of the Olympic $\mathrm{Cu}$-Au Province, and indeed across the entire footprint of this event. Regions of Hiltaba Suite or Gawler Range Volcanics equivalent magmatism are therefore locations where fluid circulation was active and are likely more prospective. An implication is that regions of the Curnamona Province where similar A-type volcanics-the Benagerie Volcanic Suite-was also erupted also has potential energy source for the IOCG mineral system.

Structural pathways in the Olympic Cu-Au Province are relatively poorly defined. At the craton scale, the lithospheric architecture established during early phases of craton development in particular the lithospheric boundary in the eastern Gawler Craton is likely to have been a primary control on the localization of early melting, magmatism and associated fluid flow [93]. Few studies have attempted to reconstruct the upper crustal structures active during the formation of the mineral system, however, those studies that have considered the structural evolution have consistently argued for north-west-south-east directed compression during the early Mesoproterozoic event (e.g., [104,147]). Hayward and Skirrow [31] have shown that the Olympic Cu-Au Province IOCG deposits developed in the hangingwall of crustal-scale faults along east-northeast- to northeast-trending faults near their intersections with major north-northwest to northwest-trending faults. In a regional compression event, the orientation of these fault systems predisposed them to dilation along structural jogs thereby facilitating fluid flow. 
Finally, physico-chemical gradients refer to changes in temperature or pressure of a hydrothermal fluid such as during emergence of fluids into dilational fault zones during seismic activity, in addition to changes in $\mathrm{pH}$, oxidation state and ligand activity. Chemical reaction of hydrothermal fluids as a result of interaction with reactive rock packages such as the carbonate units of the Wallaroo Group, or zones with early alteration minerals such as albite or magnetite [116]. Therefore, zones of reactive rock have higher potential for developing the necessary conditions for IOCG systems.

Mineral potential mapping of the four elements of the mineral system as a range of different spatial proxies by Skirrow, et al. [33] has identified areas that are more prospective for IOCG systems in South Australia (Figure 14). A key outcome of this GIS analysis is the visualization of the IOCG mineral system extending into the Curnamona Province. The potential of the Curnamona Province for IOCG systems has been discussed in the context of stratabound and replacement style Cu-Au deposits such as Portia and Kalkaroo (e.g., [6,64,119,148]). These deposits are generally more magnetite-rich and potentially represent a deeper crustal level than the hematite-rich deposits such as Olympic Dam [6], and the GIS analysis supports the concept that hematite-rich and uranium-bearing IOCG systems could be present to the north of these deposits beneath younger cover in the central-western Curnamona Province [33]. This GIS analysis is also supported by recent work on the lithospheric architecture of the Gawler Craton-Curnamona Province, which suggests regional-scale conductivity anomalies at depth beneath the Gawler Craton could have been formerly connected to similar magnitude anomalism beneath the Curnamona Province [32].

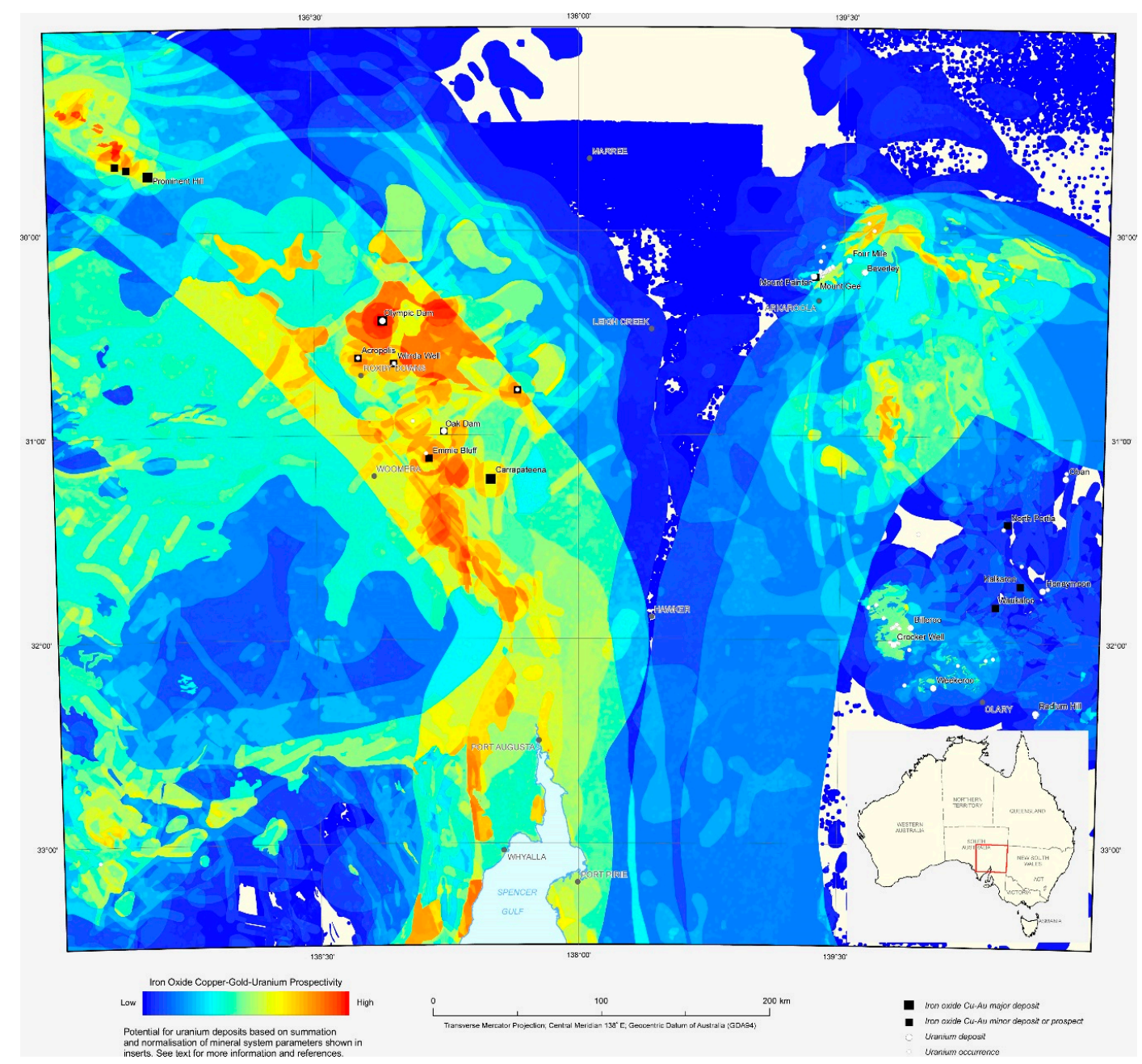

Figure 14. Prospectivity map for uranium-bearing IOCG systems in eastern South Australia (modified from [33]). This map was developed using GIS analysis based on spatial proxies for the four key elements 
of a mineral system and highlights those regions that are considered highly prospective for IOCG-type mineralisation where spatial proxies were weighted for significance and degree of certainty before being multiplied to show the overlap of the key datasets along the red to blue colour scale [33]. This GIS analysis highlights much of the region known to be prospective by proximity to deposits such as Olympic Dam and Prominent Hill and also regions of interpreted high prospectivity in other regions such as the western Curnamona Province. Map and related Geoscience Australia Record available at: https://ecat.ga.gov.au/geonetwork/srv/eng/catalog.search\#/metadata/72666.

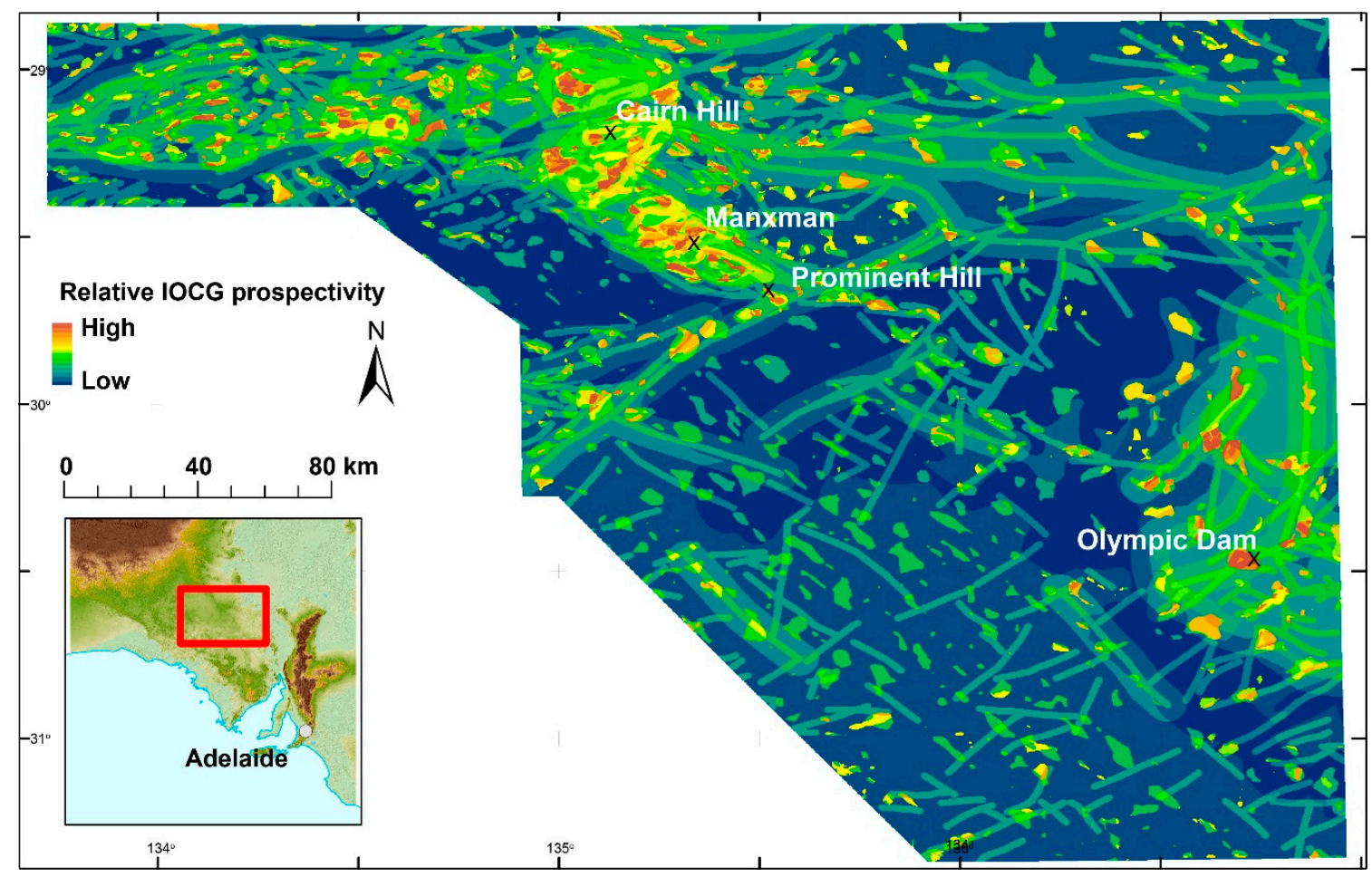

Figure 15. Results of mineral prospect mapping in the north-eastern Olympic $\mathrm{Cu}-\mathrm{Au}$ Province in the vicinity of Olympic Dam and Prominent Hill of Wise and Katona [149].

A second key outcome of this prospectivity analysis was recognition of both the potential of the regions to the north-east and south of Olympic Dam, as well as the region to the north-west of Prominent Hill, the latter of which is in the Mount Woods region [33]. Wise and Katona [149] extended this mineral potential modelling based on the four elements of a mineral system by adding potential field anomalies from residual gravity and total magnetic intensity data. In their analysis, these anomalies were attributed with descriptive statistics of the potential field grids and then combined in the GIS environment with prospectivity ranking derived from the overlapping mapable criteria representing the four mineral system factors (Figure 15). The purpose of this analysis is take into consideration the likely gravity and magnetic expression of IOCG deposits, being typically dense but weakly or non-magnetic. Across the northern Olympic $\mathrm{Cu}$-Au Province, in the vicinity of Olympic Dam and Prominent Hill, this analysis highlights the abundance of gravity anomalies that remain untested $[33,149,150]$.

\section{Conclusions}

This paper has reviewed the geological setting and mineralization of the Olympic $\mathrm{Cu}-\mathrm{Au}$ Province in the Gawler Craton, South Australia. This province hosts the Olympic Dam, Prominent Hill, and Carrapateena deposits which are currently in production along with a range of other hematite-rich and magnetite-rich iron oxide-copper-gold deposits and prospects. In addition, a brief review has been undertaken of GIS-based mineral potential modelling of this IOCG mineral system [33,149], a key 
outcome of which has been to identify sub-regions within the Olympic Cu-Au Province as well as the Curnamona Province as areas with future potential for IOCG discovery [32].

The lithospheric architecture of the Olympic $\mathrm{Cu}-\mathrm{Au}$ Province is imaged in seismic and electrical geophysical surveys and also by regional whole rock radiogenic isotope studies. These data suggest the eastern Gawler Craton is a Proterozoic terrane that is now adjacent to the central, Archean portion of the Gawler Craton and therefore that the Olympic Cu-Au Province lies above or adjacent a fundamental lithospheric boundary likely established during the early amalgamation of the craton.

The crustal expression of this IOCG system is evident as lower and mid-crustal conductivity anomalies that extend into the upper crust and indeed directly to some of the major deposits, which are co-located with destruction of seismic texture. These geophysical data suggest fluid and or magmatic migration channelled by major structures and a causative relationship between these plumbing systems and the IOCG deposits at the paleosurface. These IOCG deposits formed as a result of a major tectono-thermal event over the interval ca. 1600-1575 Ma across much of the Gawler Craton and formerly adjacent Curnamona Province. High temperature metamorphism recorded in mid-crustal rocks now exhumed to near surface was coeval with voluminous $\mathrm{K}$ - and Fe-rich, high temperature, A-type extrusive and intrusive magmatism. The mafic component of this event is subordinate at current crustal levels, where felsic magmas dominate. Nevertheless, broadly contemporaneous mafic intrusions in many IOCG deposits in the Olympic $\mathrm{Cu}-\mathrm{Au}$ Province indicates their importance in the IOCG mineral system.

The mantle component of this event was derived from highly modified, i.e., metasomatized, continental lithospheric mantle. Deformation during emplacement of these magmatic systems likely focused the fluids derived from these magmas as well as from metamorphic and basinal waters, with fluid mixing being an important process in forming IOCG-related alteration and mineralization. Progressive alteration from early, higher temperature albite, magnetite and biotite-dominant assemblages to later hematite, sericite and chlorite assemblages maps fluid evolution across the province. The presence of both magnetite-dominant and hematite-dominant mineralisation in the Olympic Cu-Au Province demonstrates that there is a spectrum of alteration types associated with the IOCG systems. This spectrum is a consequence of both fluid types, protolith chemistry and also of the degree of exhumation in any given region.

As the Olympic Cu-Au Province is almost entirely buried beneath Mesoproterozoic and Neoproterozoic-Cambrian sedimentary successions, understanding the depth and lithological character of this cover is essential for successful exploration. While these units are predominantly clastic sedimentary successions, carbonate and mafic volcanics are also present, particularly in the Stuart Shelf region, the platform sequence of the Adelaide Rift Complex to the east. Burial by these successions preserved the paleo-surface from the Mesoproterozoic is the reason the upper crust of the Olympic $\mathrm{Cu}-\mathrm{Au}$ Province has been preserved to the present.

Future exploration in this region will be reliant on improving the geophysical characterization of the terrane. Improvements in resolution of potential field data will permit greater confidence for geophysical inversion and drill targeting. This is particularly important given the magnetite to hematite transition in the formation of IOCG systems in the Olympic Cu-Au Province. This transition is a mineralogical property that can be modelled by combined gravity and magnetic inversion techniques. The results of such modelling could have implications for regional prospectivity analysis and drill hole targeting. Step changes in our understanding of the architecture of the Olympic Cu-Au Province will be provided by techniques such as magnetotellurics with 3D infill surveys from the regional scale $50 \times$ $50 \mathrm{~km}$ grid surveys of the AusLAMP program currently in progress. Furthermore, characterization of regional drillholes with consistent full element suite geochemistry and quantitative hyperspectral mineralogical data (e.g., [139]) will likewise improve the capacity to visualize regional hydrothermal fluid cells and fluid pathways. Finally, even with the best remote sensing, geochemical and other geoscientific data, mineral exploration success in this region boils down to drilling. New technologies 
that improve drilling (e.g., [151]) will play a key role in bringing forward the next wave of discoveries in the Olympic $\mathrm{Cu}-\mathrm{Au}$ Province, one of the world's premier IOCG districts.

Supplementary Materials: The following are available online at http://www.mdpi.com/2075-163X/9/6/371/s1.

Funding: This research was funded by the Geological Survey of South Australia, Department for Energy and Mining.

Acknowledgments: I acknowledge my colleagues at the Geological Survey of South Australia, many of whom provided comments on earlier versions of this paper, and in particular Adrian Fabris and Stephan Thiel. I also acknowledge the work of many minerals industry geoscientists, university researchers and Geoscience Australia in particular Roger Skirrow on the IOCG systems of southern Australia. Regional geophysical data for South Australia including magnetotelluric data can be obtained from South Australia Resource Information Gateway (SARIG), https://map.sarig.sa.gov.au/. Information on rock samples and drill holes mentioned throughout the text can also be obtained via SARIG. Data from Geoscience Australia including SEG-Y data for the Olympic Dam reflection seismic line and GIS-based mineral prospectivity mapping can be obtained from https://www.ga.gov.au/data-pubs. George Gouthas, Jonathan Irvine, Kate Robertson, Claire Wade and Tom Wise provided invaluable assistance with figures. Three anonymous reviewers provided very helpful comments.

Conflicts of Interest: The author declares no conflict of interest.

\section{References}

1. Einaudi, M.T.; Oreskes, N. Progress toward an occurrence model for Proterozoic iron oxide deposits-A comparison between the ore provinces of South Australia and southeast Missouri. Midcont. US-Permis. Terrane Olymp. Dam-Type Depos. 1990, 1932, 58-69.

2. Hitzman, M.W.; Oreskes, N.; Einaudi, M.T. Geological characteristics and tectonic setting of Proterozoic iron oxide (Cu-U-Au-LREE) deposits. Precambrian Res. 1992, 58, 241-287. [CrossRef]

3. Groves, D.I.; Bierlein, F.P.; Meinert, L.D.; Hitzman, M.W. Iron oxide copper-gold (IOCG) deposits through Earth history: Implications for origin, lithospheric setting, and distinction from other epigenetic iron oxide deposits. Econ. Geol. 2010, 105, 641-654. [CrossRef]

4. Williams, P.J.; Barton, M.D.; Fontboté, L.; De Haller, A.; Johnson, D.; Mark, G.; Marschick, R.; Oliver, N.H.S. Iron oxide-copper-gold deposits: geology, space-time distribution, and possible modes of origin. In Economic Geology 100th Anniversary Volume; Hedenquist, J.W., Thompson, J.F.H., Goldfarb, R.J., Richards, J.P., Eds.; Society of Economic Geologists: Littleton, CO, USA, 2005; pp. 371-405.

5. Grainger, C.J.; Groves, D.I.; Tallarico, F.H.B.; Fletcher, I.R. Metallogenesis of the Carajás mineral province, southern amazon craton, Brazil: Varying styles of archean through paleoproterozoic to neoproterozoic baseand precious-metal mineralisation. Ore Geol. Rev. 2008, 33, 451-489. [CrossRef]

6. Williams, P.J.; Skirrow, R. Overview of Iron Oxide-Copper-Gold Deposits in the Curnamona Province and Cloncurry District (Eastern Mount Isa Block), Australia. Hydrother. Iron Oxide Copper-Gold Related Dep. Glob. Perspect. 2000, 1, 105-122.

7. Skirrow, R.G.; Walshe, J.L. Reduced and oxidized Au-Cu-Bi iron oxide deposits of the Tennant Creek Inlier, Australia: An integrated geologic and chemical model. Econ. Geol. 2002, 97, 1167-1202. [CrossRef]

8. Oliver, N.H.S.; Cleverley, J.S.; Mark, G.; Pollard, P.J.; Fu, B.; Marshall, L.J.; Rubenach, M.J.; Williams, P.J.; Baker, T. Modeling the role of sodic alteration in the genesis of iron oxide-copper-gold deposits, Eastern Mount Isa Block, Australia. Econ. Geol. 2004, 99, 1145-1176. [CrossRef]

9. Hunt, J.A.; Baker, T.; Thorkelson, D.J. A review of iron oxide copper-gold DEPOSITS, with focus on the Wernecke Breccias, Yukon, Canada, as an example of a non-magmatic end member and implications for IOCG genesis and classification. Explor. Min. Geol. 2007, 16, 209-232. [CrossRef]

10. Ootes, L.; Snyder, D.; Davis, W.J.; Acosta-Góngora, P.; Corriveau, L.; Mumin, A.H.; Gleeson, S.A.; Samson, I.M.; Montreuil, J.F.; Potter, E.; et al. A paleoproterozoic andean-type iron oxide copper-gold environment, the Great Bear magmatic zone, Northwest Canada. Ore Geol. Rev. 2017, 81, 123-139. [CrossRef]

11. Marschik, R.; Fontboté, L.S. The candelaria-punta del cobre iron oxide $\mathrm{Cu}-\mathrm{Au}(-\mathrm{Zn}-\mathrm{Ag})$ deposits, Chile. Econ. Geol. 2001, 96, 1799-1826.

12. Sillitoe, R.H. Iron oxide-copper-gold deposits: An andean view. Min. Dep. 2003, 38, 787-812. [CrossRef]

13. Skirrow, R.G. 'Hematite-Group' IOCG \pm U Ore Systems: Tectonic Settings, Hydrothermal Characteristics, and $\mathrm{Cu}-\mathrm{Au}$ and U Mineralizing Processes. In Exploring for Iron Oxide Copper-Gold Deposits: Canada and Global 
Analogues; Corriveau, L., Mumin, H., Eds.; Shortcourse Notes, GAC-MAC-SEG-SGA 2008, Quebec City, 29-30th May 2008; Geological Association of Canada: St. John's, NL, Canada, 2010; pp. 39-58.

14. Williams, P.J. 'Magnetite-Group' IOCGs with Special Reference to Cloncurry (NW Queensland) and Northern Sweden: Settings, Alteration, Deposit Characteristics, Fluid Sources, and their Relationship to Apatite-rich Iron Ores. In Exploring for Iron Oxide Copper-Gold Deposits: Canada and Global Analogues; Corriveau, L., Mumin, A.H., Eds.; Shortcourse Notes, GAC-MAC-SEG-SGA 2008, Quebec City, 29-30th May 2008; Geological Association of Canada: St. John's, NL, Canada, 2010; pp. 23-29.

15. Davidson, G.J. The shallow to mid-crustal family of iron oxide copper-gold deposits: size, alteration and mechanisms of formation. In Giant Ore Deposits: Characteristics, Genesis and Exploration; Cooke, D.R., Pongratz, J., Eds.; Special Publication 4-Centre for Ore Deposit and Exploration Studies (CODES): Hobart, Australia, 2002; Volume 4, pp. 79-102.

16. Gleeson, S.A.; Smith, M.P. The sources and evolution of mineralising fluids in iron oxide-copper-gold systems, Norrbotten, Sweden: Constraints from $\mathrm{Br} / \mathrm{Cl}$ ratios and stable $\mathrm{Cl}$ isotopes of fluid inclusion leachates. Geochim. Cosmochim. Acta 2009, 73, 5658-5672. [CrossRef]

17. Chen, H. External sulphur in IOCG mineralization: Implications on definition and classification of the IOCG clan. Ore Geol. Rev. 2013, 51, 74-78. [CrossRef]

18. Xavier, R.P.; Wiedenbeck, M.; Trumbull, R.B.; Dreher, A.M.; Monteiro, L.V.S.; Rhede, D.; Araújo, C.E.G.; Torresi, I. Tourmaline B-isotopes fingerprint marine evaporites as the source of high-salinity ore fluids in iron oxide copper-gold deposits, Carajás Mineral Province (Brazil). Geology 2008, 36, 743-746. [CrossRef]

19. Corriveau, L.; Montreuil, J.F.; Potter, E.G. Alteration facies linkages among iron oxide copper-gold, iron oxide-apatite, and affiliated deposits in the Great Bear Magmatic Zone, Northwest Territories, Canada. Econ. Geol. 2016, 111, 2045-2072. [CrossRef]

20. Ehrig, K.; McPhie, J.; Kamenetsky, V. Geology and mineralogical zonation of the Olympic Dam iron oxide $\mathrm{Cu}-\mathrm{U}-\mathrm{Au}-\mathrm{Ag}$ deposit, South Australia. In Geology and Genesis of Major Copper Deposits and Districts of the World: A Tribute to Richard H. Sillitoe; Hedenquist, J.W., Harris, M., Camus, F., Eds.; Society of Economic Geologists Special Publication 16: Littleton, CO, USA, 2012; pp. 237-267.

21. Skirrow, R.G.; Bastrakov, E.N.; Barovich, K.; Fraser, G.L.; Creaser, R.A.; Fanning, C.M.; Raymond, O.L.; Davidson, G.J. Timing of iron oxide $\mathrm{Cu}-\mathrm{Au}-(\mathrm{U})$ hydrothermal activity and $\mathrm{Nd}$ isotope constraints on metal sources in the Gawler Craton, South Australia. Econ. Geol. 2007, 102, 1441-1470. [CrossRef]

22. Belperio, A.; Flint, R.; Freeman, H. Prominent Hill-A hematite-dominated, iron-oxide copper-gold system. Econ. Geol. 2007, 102, 1499-1510. [CrossRef]

23. Ismail, R.; Ciobanu, C.L.; Cook, N.J.; Teale, G.S.; Giles, D.; Mumm, A.S.; Wade, B. Rare earths and other trace elements in minerals from skarn assemblages, Hillside iron oxide-copper-gold deposit, Yorke Peninsula, South Australia. Lithos 2014, 184, 456-477. [CrossRef]

24. Porter, T.M. The Carrapateena iron oxide copper gold deposit, Gawler Craton, South Australia: A review. In Hydrothermal Iron Oxide Copper-Gold E Related Deposits: A Global Perspective, v. 3-Advances in the Understanding of IOCG Deposits; Porter, T.M., Ed.; PGC Publishing: Adelaide, Australia, 2010; pp. 191-200.

25. Schlegel, T.U.; Heinrich, C.A. Lithology and hydrothermal alteration control the distribution of copper grade in the prominent hill iron oxide-copper-gold deposit (Gawler Craton, South Australia). Econ. Geol. 2015, 110, 1953-1994. [CrossRef]

26. Huang, Q.; Kamenetsky, V.S.; Ehrig, K.; McPhie, J.; Kamenetsky, M.; Cross, K.; Meffre, S.; Agangi, A.; Chambefort, I.; Direen, N.G.; et al. Olivine-phyric basalt in the Mesoproterozoic Gawler silicic large igneous province, South Australia: Examples at the Olympic Dam iron oxide $\mathrm{Cu}-\mathrm{U}-\mathrm{Au}-\mathrm{Ag}$ deposit and other localities. Precambrian Res. 2016, 281, 185-199. [CrossRef]

27. Mauger, A.J.; Ehrig, K.; Kontonikas-Charos, A.; Ciobanu, C.L.; Cook, N.J.; Kamenetsky, V.S. Alteration at the Olympic Dam IOCG-U deposit: Insights into distal to proximal feldspar and phyllosilicate chemistry from infrared reflectance spectroscopy. Aust. J. Earth Sci. 2016, 63, 959-972.

28. Apukhtina, O.B.; Kamenetsky, V.S.; Ehrig, K.; Kamenetsky, M.B.; Maas, R.; Thompson, J.; McPhie, J.; Ciobanu, C.L.; Cook, N.J. Early, deep magnetite-fluorapatite mineralization at the Olympic Dam Cu-U-Au-Ag deposit, South Australia. Econ. Geol. 2017, 112, 1531-1542. [CrossRef]

29. Kontonikas-Charos, A.; Ciobanu, C.L.; Cook, N.J.; Ehrig, K.; Krneta, S.; Kamenetsky, V.S. Rare earth element geochemistry of feldspars: examples from Fe-oxide $\mathrm{Cu}-\mathrm{Au}$ systems in the Olympic $\mathrm{Cu}$-Au Province, South Australia. Mineral. Petrol. 2018, 112, 145-172. [CrossRef] 
30. Hand, M.; Reid, A.; Jagodzinski, E. Tectonic framework and evolution of the Gawler Craton, South Australia. Econ. Geol. 2007, 102, 1377-1395. [CrossRef]

31. Hayward, N.; Skirrow, R. Geodynamic setting and controls on iron oxide $\mathrm{Cu}-\mathrm{Au}( \pm \mathrm{U})$ ore in the Gawler Craton, South Australia. In Hydrothermal Iron Oxide Copper-Gold and Related Deposits: A Global Perspective, Volume 3, Advances in the Understanding of Iocg Deposits; Porter, T.M., Ed.; PGC Publishing: Adelaide, Australia, 2010; pp. 105-131.

32. Skirrow, R.G.; Wielen, S.E.; Champion, D.C.; Czarnota, K.; Thiel, S. Lithospheric architecture and mantle metasomatism linked to iron oxide $\mathrm{Cu}$-Au ore formation: Multidisciplinary evidence from the Olympic Dam region, South Australia. Geochem. Geophys. Geosyst. 2018, 19, 2673-2705. [CrossRef]

33. Skirrow, R.; Schofield, A.; Connelly, D.P. Uranium-rich iron oxide copper-gold. In An Assessment of the Uranium and Geothermal Prospectivity of East-Central South Australia; Huston, D.L., van der Wielen, S.E., Eds.; Geoscience Australia Record 2011/34: Canberra, Australia, 2011; pp. 37-68.

34. Wyborn, L.A.I.; Heinrich, C.A.; Jaques, A. Australian Proterozoic mineral systems: Essential ingredients and mappable criteria. In Proceedings of the AusIMM Annual Conference, Darwin, Australia, 5-9 August 1994; Volume 5, pp. 109-115.

35. Occhipinti, S.A.; Metelka, V.; Lindsay, M.D.; Hollis, J.A.; Aitken, A.R.A.; Tyler, I.M.; Miller, J.M.; McCuaig, T.C. Multicommodity mineral systems analysis highlighting mineral prospectivity in the Halls Creek Orogen. Ore Geol. Rev. 2016, 72, 86-113. [CrossRef]

36. McCuaig, T.C.; Beresford, S.; Hronsky, J. Translating the mineral systems approach into an effective exploration targeting system. Ore Geol. Rev. 2010, 38, 128-138. [CrossRef]

37. Myers, J.S.; Shaw, R.D.; Tyler, I.M. Tectonic evolution of Proterozoic Australia. Tectonics 1996, 15, 1431-1446. [CrossRef]

38. Payne, J.L.; Hand, M.; Barovich, K.; Reid, A.J.; Evans, D.A.D. Correlations and reconstruction models for the 2500-1500 Ma evolution of the Mawson Continent. In Palaeoproterozoic Supercontinents and Global Evolution; Reddy, S.M., Mazumder, R., Evans, D.A.D., Collins, A.S., Eds.; Geological Society Special Publications 323: London, UK, 2009; pp. 319-355.

39. Fitzsimons, I.C.W. Proterozoic basement provinces of southern and southwestern Australia, and their correlation with Antarctica. Geol. Soc. Lond. Spec. Publ. 2003, 206, 93-130. [CrossRef]

40. Pehrsson, S.J.; Eglington, B.M.; Evans, D.A.D.; Huston, D.; Reddy, S.M. Metallogeny and its link to orogenic style during the Nuna supercontinent cycle. Geol. Soc. Lond. Spec. Publ. 2016, 424, 83-94. [CrossRef]

41. Pehrsson, S.J.; Berman, R.G.; Eglington, B.; Rainbird, R. Two Neoarchean supercontinents revisited: The case for a Rae family of cratons. Precambrian Res. 2013, 232, 27-43. [CrossRef]

42. Halpin, J.A.; Reid, A.J. Earliest Paleoproterozoic high-grade metamorphism and orogenesis in the Gawler Craton, South Australia: The southern cousin in the Rae family? Precambrian Res. 2016, 276, 123-144. [CrossRef]

43. Fraser, G.; McAvaney, S.; Neumann, N.; Szpunar, M.; Reid, A. Discovery of early Mesoarchean crust in the eastern Gawler Craton, South Australia. Precambrian Res. 2010, 179, 1-21. [CrossRef]

44. Swain, G.; Woodhouse, A.; Hand, M.; Barovich, K.; Schwarz, M.; Fanning, C.M. Provenance and tectonic development of the late Archaean Gawler Craton, Australia; U-Pb zircon, geochemical and Sm-Nd isotopic implications. Precambrian Res. 2005, 141, 106-136. [CrossRef]

45. Reid, A.J.; Fricke, C.; Cowley, W.M. Extent of the low-grade Archaean Devils Playground Volcanics in the north-eastern Gawler Craton: Evidence from recent PACE drilling. MESA J 2009, 54, 9-19.

46. Hoatson, D.M.; Sun, S.S.; Duggan, M.B.; Davies, M.B.; Daly, S.J.; Purvis, A.C. Late Archaean Lake Harris Komatiite, central Gawler Craton, South Australia: Geologic setting and geochemistry. Econ. Geol. 2005, 100, 349-374.

47. Szpunar, M.; Hand, M.; Barovich, K.; Belousova, E.; Jagodzinski, E.A. Isotopic and geochemical constraints on the Paleoproterozoic Hutchison Group, southern Australia: Implications for Paleoproterozoic continental reconstructions. Precambrian Res. 2011, 187, 99-126. [CrossRef]

48. Payne, J.L.; Ferris, G.; Barovich, K.M.; Hand, M. Pitfalls of classifying ancient magmatic suites with tectonic discrimination diagrams: An example from the Paleoproterozoic Tunkillia Suite, southern Australia. Precambrian Res. 2010, 177, 227-240. [CrossRef] 
49. Howard, K.; Hand, M.; Barovich, K.; Belousova, E. Provenance of late Palaeoproterozoic cover sequences in the central Gawler Craton: Exploring stratigraphic correlations in eastern Proterozoic Australia using detrital zircon ages, Hf and Nd isotopic data. Aust. J. Earth Sci. 2011, 58, 475-500. [CrossRef]

50. Swain, G.; Barovich, K.; Hand, M.; Ferris, G.; Schwarz, M. Petrogenesis of the St Peter Suite, southern Australia: Arc magmatism and Proterozoic crustal growth of the South Australian Craton. Precambrian Res. 2008, 166, 283-296. [CrossRef]

51. Flint, R.B.; Rankin, L.R.; Fanning, C.M. Definition; the Palaeoproterozoic St. Peter Suite of the western Gawler Craton. Q. Geol. Notes-Geol. Surv. S. Aust. 1990, 114, 2-8.

52. Flint, R.B.; Blissett, A.H.; Conor, C.H.H.; Cowley, W.M.; Cross, K.C.; Creaser, R.A.; Daly, S.J.; Krieg, G.W.; Major, R.B.; Teale, G.S.; et al. Mesoproterozoic. In The geology of South Australia; Volume 1, The Precambrian; Drexel, J.F., Preiss, W.V., Parker, A.J., Eds.; Geological Survey of South Australia, Bulletin 54: Adelaide, Australia, 1993; pp. 106-169.

53. Allen, S.R.; McPhie, J.; Ferris, G.; Cadd, A.G. Evolution and architecture of a large felsic igneous province in western Laurentia: The 1.6 Ga Gawler Range Volcanics, South Australia. J Volcanol. Geotherm. Res. 2008, 172, 132-147. [CrossRef]

54. Daly, S.J.; Fanning, C.M.; Fairclough, M.C. Tectonic evolution and exploration potential of the Gawler Craton, South Australia. AGSO J. Aust. Geol. Geophys. 1998, 17, 145-168.

55. Cutts, K.; Hand, M.; Kelsey, D.E. Evidence for early Mesoproterozoic (ca. 1590 Ma) ultrahigh-temperature metamorphism in southern Australia. Lithos 2011, 124, 1-16. [CrossRef]

56. Brotodewo, A.; Tiddy, C.J.; Reid, A.; Wade, C.; Conor, C. Relationships between magmatism and deformation in northern Yorke Peninsula and southeastern Proterozoic Australia. Aust. J. Earth Sci. 2018, 65, 619-641. [CrossRef]

57. Budd, A.R.; Fraser, G.L. Geological relationships and ${ }^{40} \mathrm{Ar} /{ }^{39} \mathrm{Ar}$ age constraints on gold mineralisation at Tarcoola, central Gawler gold province, South Australia. Aust. J. Earth Sci. 2004, 51, 685-700. [CrossRef]

58. Budd, A.R.; Skirrow, R.G. The nature and origin of gold deposits of the Tarcoola goldfield and implications for the central Gawler gold province, South Australia. Econ. Geol. 2007, 102, 1541-1563. [CrossRef]

59. Reid, A.J.; Jagodzinski, E.A.; Armit, R.J.; Dutch, R.A.; Kirkland, C.L.; Betts, P.G.; Schaefer, B.F. U-Pb and Hf isotopic evidence for Neoarchean and Paleoproterozoic basement in the buried northern Gawler Craton, South Australia. Precambrian Res. 2014, 250, 127-142. [CrossRef]

60. Morrissey, L.J.; Barovich, K.M.; Hand, M.; Howard, K.E.; Payne, J.L. Magmatism and metamorphism at ca. $1.45 \mathrm{Ga}$ in the northern Gawler Craton: The Australian record of rifting within Nuna (Columbia). Geosci. Front. 2019, 10, 175-194. [CrossRef]

61. Fraser, G.; Lyons, P. Timing of Mesoproterozoic tectonic activity in the northwestern Gawler Craton constrained by ${ }^{40} \mathrm{Ar} /{ }^{39} \mathrm{Ar}$ geochronology. Precambrian Res. 2006, 151, 160-184. [CrossRef]

62. Fraser, G.; Reid, A.; Stern, R. Timing of deformation and exhumation across the Karari Shear Zone, north-western Gawler Craton, South Australia. Aust. J. Earth Sci. 2012, 59, 547-570. [CrossRef]

63. Fanning, C.M.; Flint, R.B.; Preiss, W.V. Geochronology of the pandurra formation. Q. Geol. Notes-Geol. Surv. S. Aust. 1983, 88, 11-16.

64. Reid, A.J.; Fabris, A. Influence of pre-existing low metamorphic grade sedimentary successions on the distribution of iron oxide-copper-gold mineralization in the Olympic Cu-Au province, Gawler craton. Econ. Geol. 2015, 110, 2147-2157. [CrossRef]

65. Conor, C.C.H.; Preiss, W.V. Understanding the 1720-1640 Ma Palaeoproterozoic Willyama Supergroup, Curnamona Province, southeastern Australia: Implications for tectonics, basin evolution and ore genesis. Precambrian Res. 2008, 166, 297-317. [CrossRef]

66. Haydon, R.C.; McConachy, G.W. The stratigraphic setting of Pb-Zn-Ag mineralization at Broken Hill. Econ. Geol. 1987, 82, 826-856. [CrossRef]

67. Groves, I.M.; Groves, D.I.; Bierlein, F.P.; Broome, J.; Penhall, J. Recognition of the hydrothermal feeder to the structurally inverted, giant Broken Hill deposit, New South Wales, Australia. Econ. Geol. 2008, 103, 1389-1394. [CrossRef]

68. Wade, C.E. Definition of the mesoproterozoic ninnerie supersuite, Curnamona Province, South Australia. MESA J. 2011, 62, 25-42.

69. Wade, C.E.; Reid, A.J.; Wingate, M.T.D.; Jagodzinski, E.A.; Barovich, K. Geochemistry and geochronology of the c. 1585 Ma Benagerie Volcanic Suite, southern Australia: Relationship to the Gawler Range Volcanics 
and implications for the petrogenesis of a Mesoproterozoic silicic large igneous province. Precambrian Res. 2012, 206, 17-35. [CrossRef]

70. Page, R.W.; Stevens, B.P.J.; Gibson, G.M. Geochronology of the Sequence Hosting the Broken Hill Pb-Zn-Ag Orebody, Australia. Econ. Geol. 2005, 100, 633-661.

71. Forbes, C.J.; Giles, D.; Betts, P.G.; Weinberg, R.; Kinny, P.D. Dating prograde amphibolite and granulite facies metamorphism using in situ monazite U-Pb SHRIMP analysis. J. Geol. 2007, 115, 691-705. [CrossRef]

72. Skirrow, R.G.; Ashley, P.M.; Suzuki, K.; McNaughton, N.J. Time-Space framework of Cu-Au(-Mo) and regional alteration systems in the curnamona province. Aust. Geol. Surv. Organ. Record 2000, 10, 83-86.

73. Armistead, S.E.; Betts, P.G.; Ailleres, L.; Armit, R.J.; Williams, H.A. Cu-Au mineralisation in the Curnamona Province, South Australia: A hybrid stratiform genetic model for Mesoproterozoic IOCG systems in Australia. Ore Geol. Rev. 2018, 94, 104-117. [CrossRef]

74. Preiss, W.V. The Adelaide Geosyncline: Late Proterozoic Stratigraphy, Sedimentation, Palaeontology and Tectonics; Geological Survey of South Australia-Bulletin 53: Adelaide, Australia, 1987; p. 428.

75. Preiss, W.V. The Adelaide Geosyncline of South Australia and its significance in Neoproterozoic continental reconstruction. Precambrian Res. 2000, 100, 21-63. [CrossRef]

76. Lambert, I.B.; Knutson, J.; Donnelly, T.H.; Etminan, H. Stuart Shelf-Adelaide Geosyncline copper province, South Australia. Econ. Geol. 1987, 82, 108-123. [CrossRef]

77. Szpunar, M.; Wade, B.; Hand, M.; Barovich, K. Timing of Proterozoic high-grade metamorphism in the Barossa Complex, southern South Australia: Exploring the extent of the 1590 Ma event. MESA J. 2007, 47, $21-27$.

78. Meaney, K.J. Proterozoic Crustal Growth in the Southeastern Gawler Craton: The Development of the Barossa Complex, and an Assessment of the Detrital Zircon Method. Ph.D. Thesis, School of Physical Sciences, University of Adelaide, Adelaide, Australia, December 2017.

79. Morrissey, L.J.; Hand, M.; Wade, B.P.; Szpunar, M. Early Mesoproterozoic metamorphism in the Barossa Complex, South Australia: links with the eastern margin of Proterozoic Australia. Aust. J. Earth Sci. 2013, 1-27. [CrossRef]

80. Reid, A.J.; Hand, M. Mesoarchean to Mesoproterozoic evolution of the southern Gawler Craton, South Australia. Episodes 2012, 35, 216-225.

81. Powell, C.M.; Preiss, W.V.; Gatehouse, C.G.; Krapez, B.; Li, Z.X. South Australian record of a Rodinian epicontinental basin and its mid-Neoproterozoic breakup ( 700 Ma) to form the Palaeo-Pacific Ocean. Tectonophysics 1994, 237, 113-140. [CrossRef]

82. Flottmann, T.; Haines, P.; Jago, J.; James, P.; Belperio, A.P.; Gum, J. Formation and reactivation of the Cambrian Kanmantoo Trough, SE Australia: implications for early Palaeozoic tectonics at eastern Gondwana's plate margin. J. Geol. Soc. 1998, 155, 525-539. [CrossRef]

83. Foden, J.; Elburg, M.A.; Dougherty-Page, J.; Burtt, A. The timing and duration of the delamerian orogeny: correlation with the ross orogen and implications for gondwana assembly. J. Geol. 2006, 114, 189-210. [CrossRef]

84. Preiss, W.V. Delamerian Orogeny. In The geology of South Australia; Volume 2, The Phanerozoic; Drexel, J.F., Preiss, W.V., Parker, A.J., Eds.; Geological Survey of South Australia-Bulletin 54: Adelaide, Australia, 1995; pp. 45-59.

85. Alexander, E.M.; Hibburt, J. (Eds.) Petroleum Geology of South Australia. Volume 2: Eromanga Basin; Report Book 96/020; South Australia, Department of Mines and Energy: Adelaide, Australia, 1996.

86. Hou, B.; Frakes, L.; Sandiford, M.; Worrall, L.; Keeling, J.; Alley, N.F. Cenozoic Eucla Basin and associated palaeovalleys, southern Australia-climatic and tectonic influences on landscape evolution, sedimentation and heavy mineral accumulation. Sediment. Geol. 2008, 203, 112-130. [CrossRef]

87. Kennett, B.L.; Fichtner, A.; Fishwick, S.; Yoshizawa, K. Australian seismological reference model (AuSREM): Mantle component. Geophys. J. Int. 2013, 192, 871-887. [CrossRef]

88. Korsch, R.J.; Blewett, R.S.; Giles, D.; Reid, A.J.; Neumann, N.; Fraser, G.L.; Holzshuh, J.; Costelloe, R.D.; Roy, I.G.; Kennett, B.L.N.; et al. Geological Interpretation of the Deep Seismic Reflection and Magnetotelluric Line 08GA-OM1: Gawler Craton-Officer Basin-Musgrave Province-Amadeus Basin (GOMA), South Australia and Northern Territory; Korsch, R.J., Kositcin, N., Eds.; GOMA (Gawler Craton-Officer Basin-Musgrave Province-Amadeus Basin) Seismic and MT Workshop 2010; Geoscience Australia, Record 2010/39: Canberra, Australia; pp. 63-86. 
89. Drummond, B.; Lyons, P.; Goleby, B.; Jones, L. Constraining models of the tectonic setting of the giant Olympic Dam iron oxide-copper-gold deposit, South Australia, using deep seismic reflection data. Tectonophysics 2006, 420, 91-103. [CrossRef]

90. Wise, T.; Reid, A.J.; Jakica, S.; Fabris, A.J.; van der Wielen, S.E.; Ziramov, S.; Pridmore, D. Olympic Dam seismic revisited: Reprocessing of deep crustal seismic using partially preserved amplitude processing. MESA J. 2015, 78, 17-28. [CrossRef]

91. Thiel, S.; Heinson, G. Crustal imaging of a mobile belt using magnetotellurics: An example of the Fowler Domain in South Australia. J. Geophys. Res. Solid Earth 2010, 115. [CrossRef]

92. Thiel, S.; Heinson, G. Electrical conductors in Archean mantle-Result of plume interaction? Geophys. Res. Lett. 2013, 40, 2947-2952. [CrossRef]

93. Heinson, G.; Didana, Y.; Soeffky, P.; Thiel, S.; Wise, T. The crustal geophysical signature of a world-class magmatic mineral system. Sci. Rep. 2018, 8, 10608. [CrossRef] [PubMed]

94. Curtis, S.; Thiel, S. Identifying lithospheric boundaries using magnetotellurics and Nd isotope geochemistry: An example from the Gawler Craton, Australia. Precambrian Res. 2019, 320, 403-423. [CrossRef]

95. Motta, J.G.; Betts, P.G.; Souza-Filho, C.R.; Thiel, S.; Curtis, S.; Armit, R.J. Proxies for basement structure and its implications for mesoproterozoic metallogenic Provinces in the Gawler Craton. J. Geophys. Res. Solid Earth 2019, 124. [CrossRef]

96. Wade, C.E.; Payne, J.L.; Barovich, K.M.; Reid, A.J. Heterogeneity of the sub-continental lithospheric mantle and 'non-juvenile' mantle additions to a Proterozoic silicic large igneous province. Lithos 2019. [CrossRef]

97. Champion, D.C.; Huston, D.L. Radiogenic isotopes, ore deposits and metallogenic terranes: Novel approaches based on regional isotopic maps and the mineral systems concept. Ore Geol. Rev. 2015, 76, 229-256. [CrossRef]

98. Hronsky, J.M.A.; Groves, D.I.; Loucks, R.R.; Begg, G.C. A unified model for gold mineralisation in accretionary orogens and implications for regional-scale exploration targeting methods. Miner. Depos. 2012, 47, 339-358. [CrossRef]

99. Griffin, W.L.; Begg, G.C.; O'Reilly, S.Y. Continental-root control on the genesis of magmatic ore deposits. Nat. Geosci. 2013, 6, 905-910. [CrossRef]

100. Heinson, G.; Direen, N.G.; Gill, R.M. Magnetotelluric evidence for a deep-crustal mineralizing system beneath the Olympic Dam iron oxide copper-gold deposit, southern Australia. Geology 2006, 34, 573-576. [CrossRef]

101. Thiel, S.; Reid, A.; Heinson, G.; Robertson, K. Insights into lithospheric architecture, fertilisation and fluid pathways from AusLAMP MT. Aust. Soc. Explor. Geophys. Ext. Abstr. 2016, 2016, 1-6. [CrossRef]

102. Giles, C.W. Petrogenesis of the Proterozoic Gawler Range volcanics, South Australia. Precambrian Res. 1988, 40, 407-427. [CrossRef]

103. Wade, B.; Barovich, K.; Hand, M.; Scrimgeour, I.R.; Close, D.F. Evidence for early Mesoproterozoic arc-related magmatism in the Musgrave Block, central Australia: Implications for Proterozoic crustal growth and tectonic reconstructions of Australia. J. Geol. 2006, 114, 43-63. [CrossRef]

104. Betts, P.G.; Giles, D.; Foden, J.; Schaefer, B.F.; Mark, G.; Pankhurst, M.J.; Forbes, C.J.; Williams, H.A.; Chalmers, N.C.; Hills, Q. Mesoproterozoic plume-modified orogenesis in eastern Precambrian Australia. Tectonics 2009, 28. [CrossRef]

105. Zhang, S.; Li, Z.X.; Evans, D.A.D.; Wu, H.; Li, H.; Dong, J. Pre-Rodinia supercontinent Nuna shaping up: A global synthesis with new paleomagnetic results from North China. Earth Planet. Sci. Lett. 2012, 353, 145-155. [CrossRef]

106. Pisarevsky, S.A.; Elming, S.Å.; Pesonen, L.J.; Li, Z.X. Mesoproterozoic paleogeography: Supercontinent and beyond. Precambrian Res. 2014, 244, 207-225. [CrossRef]

107. Allen, S.R.; Simpson, C.J.; McPhie, J.; Daly, S.J. Stratigraphy, distribution and geochemistry of widespread felsic volcanic units in the Mesoproterozoic Gawler Range Volcanics, South Australia. Aust. J. Earth Sci. 2003, 50, 97-112. [CrossRef]

108. Budd, A.R.; Wyborn, L.A.I.; Bastrakova, I.V. The Metallogenic Potential of Australian Proterozoic Granites; Geoscience Australia Record 2001/12: Canberra, Australia, 2001; p. 152.

109. Forbes, C.J.; Giles, D.; Hand, M.; Betts, P.G.; Suzuki, K.; Chalmers, N.C.; Dutch, R. Using P-T paths to interpret the tectonothermal setting of prograde metamorphism: An example from the northeastern Gawler Craton, South Australia. Precambrian Res. 2011, 185, 65-85. [CrossRef] 
110. Stevens, B.P.J. Post-depositional history of the Willyama Supergroup in the Broken Hill Block, NSW. Aust. J. Earth Sci. 1986, 33, 73-98. [CrossRef]

111. McPhie, J.; Kamenetsky, V.S.; Chambefort, I.; Ehrig, K.; Green, N. Origin of the supergiant Olympic Dam $\mathrm{Cu}-\mathrm{U}-\mathrm{Au}-\mathrm{Ag}$ deposit, South Australia: Was a sedimentary basin involved? Geology 2011, 39, 795-798. [CrossRef]

112. Curtis, S.; Wade, C.; Reid, A. Sedimentary basin formation associated with a silicic large igneous province: Stratigraphy and provenance of the Mesoproterozoic Roopena Basin, Gawler Range Volcanics. Aust. J. Earth Sci. 2018, 65, 447-463. [CrossRef]

113. Tassara, S.; González-Jiménez, J.M.; Reich, M.; Schilling, M.E.; Morata, D.; Begg, G.; Saunders, E.; Griffin, W.L.; O'Reilly, S.Y.; Grégoire, M.; et al. Plume-subduction interaction forms large auriferous provinces. Nat. Commun. 2017, 8, 843. [CrossRef] [PubMed]

114. Pankhurst, M.J.; Schaefer, B.F.; Betts, P.G.; Phillips, N.; Hand, M. A Mesoproterozoic continental flood rhyolite province, the Gawler Ranges, Australia: the end member example of the Large Igneous Province clan. Solid Earth 2011, 2, 25-33. [CrossRef]

115. McPhie, J.; Kamenetsky, V.; Allen, S.R.; Ehrig, K.; Agangi, A.; Bath, A. The fluorine link between a supergiant ore deposit and a silicic large igneous province. Geology 2011, 39, 1003-1006. [CrossRef]

116. Bastrakov, E.N.; Skirrow, R.G.; Davidson, G.J. Fluid evolution and origins of iron oxide Cu-Au prospects in the Olympic Dam district, Gawler Craton, South Australia. Econ. Geol. 2007, 102, 1415-1440. [CrossRef]

117. Gow, P.A.; Wall, V.J.; Oliver, N.H.S.; Valenta, R.K. Proterozoic iron oxide (Cu-U-Au-REE) deposits: Further evidence of hydrothermal origin. Geology 1994, 22, 633-636. [CrossRef]

118. Cowley, W.M.; Conor, C.H.H.; Zang, W. New and revised Proterozoic stratigraphic units on northern Yorke Peninsula. MESA J. 2003, 29, 46-58.

119. Conor, C.C.H.; Raymond, O.; Baker, T.; Teale, G.S.; Say, P.; Lowe, G. Alteration and mineralisation in the Moonta-Wallaroo copper-gold mining field region, Olympic Domain, South Australia. In Hydrothermal Iron Oxide Copper-Gold E Related Deposits: A Global Perspective, v. 3-Advances in the Understanding of IOCG Deposits; Porter, T.M., Ed.; PGC Publishing: Adelaide, Australia, 2010; pp. 1-24.

120. Cherry, A.R.; Ehrig, K.; Kamenetsky, V.S.; McPhie, J.; Crowley, J.L.; Kamenetsky, M.B. Precise geochronological constraints on the origin, setting and incorporation of ca. $1.59 \mathrm{Ga}$ surficial facies into the Olympic Dam Breccia Complex, South Australia. Precambrian Res. 2018, 315, 162-178. [CrossRef]

121. Montreuil, J.F.; Corriveau, L.; Grunsky, E.C. Compositional data analysis of hydrothermal alteration in IOCG systems, Great Bear magmatic zone, Canada: to each alteration type its own geochemical signature. Geochem. Explor. Environ. Anal. 2013, 13, 229-247. [CrossRef]

122. Van der Wielen, S.; Fabris, A.; Halley, S.W.; Keeling, J.L.; Mauger, A.J.; Gordon, G.A.; Keeping, T.; Giles, D.; Hill, S.M. An exploration strategy for IOCG mineral systems under deep cover. MESA J. 2013, 71, 18-30.

123. Fabris, A.; Katona, L.; Gordon, G.A.; Reed, G.; Keeping, T.; Gouthas, G.; Swain, G. Characterisation and mapping of $\mathrm{Cu}-\mathrm{Au}$ skarn systems in the Punt Hill region, Olympic Cu-Au Province. MESA J. 2018, 87, 15-27.

124. Skirrow, R.G.; Bastrakov, E.; Davidson, G.; Raymond, O.L.; Heithersay, P. The geological framework, distribution and controls of Fe-oxide and related alteration, and $\mathrm{Cu}$-Au mineralisation in the Gawler Craton, South Australia. Part II: Alteration and mineralisation. In Hydrothermal Iron Oxide Copper-Gold and Related Deposits: A Global Perspective; Porter, T.M., Ed.; PGC Publishing: Adelaide, Australia, 2002; Volume 2, pp. 33-47.

125. Reid, A.J.; Swain, G.S.; Mason, D.; Maas, R. Nature and timing of Cu-Au-Zn-Pb mineralisation at Punt Hill, eastern Gawler Craton. MESA J. 2011, 60, 7-17.

126. Jagodzinski, E.A.; Reid, A.J. PACE Geochronology: Results of Collaborative Geochronology Projects, 2013-2015; Report Book 2015/00003; Department of the Premier and Cabinet: Adelaide, Australia, 2015.

127. Davidson, G.J.; Paterson, H.L.; Meffre, S.; Berry, R.F. Characteristics and origin of the Oak Dam East breccia-hosted, iron oxide $\mathrm{Cu}-\mathrm{U}-(\mathrm{Au})$ deposit: Olympic Dam region, Gawler Craton, South Australia. Econ. Geol. 2007, 102, 1471-1498. [CrossRef]

128. Krneta, S.; Ciobanu, C.L.; Cook, N.J.; Ehrig, K.; Kontonikas-Charos, A. Apatite at Olympic Dam, South Australia: A petrogenetic tool. Lithos 2016, 262, 470-485. [CrossRef]

129. Krneta, S.; Cook, N.J.; Ciobanu, C.L.; Ehrig, K.; Kontonikas-Charos, A. The Wirrda Well and Acropolis prospects, Gawler Craton, South Australia: Insights into evolving fluid conditions through apatite chemistry. J. Geochem. Explor. 2017, 181, 276-291. [CrossRef] 
130. Reid, A.J.; Smith, R.N.; Baker, T.; Jagodzinski, E.A.; Selby, D.; Gregory, C.J.; Skirrow, R.G. Re-Os dating of molybdenite within hematite-breccias from the Vulcan $\mathrm{Cu}$-Au prospect, Olympic $\mathrm{Cu}$-Au Province, South Australia. Econ. Geol. 2013, 108, 883-894. [CrossRef]

131. Kontonikas-Charos, A.; Ciobanu, C.L.; Cook, N.J. Albitization and redistribution of REE and Y in IOCG systems: Insights from Moonta-Wallaroo, Yorke Peninsula, South Australia. Lithos 2014, 208-209, 178-201. [CrossRef]

132. Clark, J.; Cook, N.; Reid, A.J.; Fabris, A.; Ciobanu, C.; Hill, P. The Cairn Hill magnetite-sulfide deposit, Mount Woods inlier, South Australia: Ore genesis and spatial-temporal relationships with iron oxide copper-gold systems in the Gawler craton. In Proceedings of the Society of Ecomonic Geologists 2015, Hobart, Tasmania, Australia, 27-30 September 2015; p. 1.

133. Uvarova, Y.A.; Pearce, M.A.; Liu, W.; Cleverley, J.S.; Hough, R.M. Geochemical signatures of copper redistribution in IOCG-type mineralisation, Gawler Craton, South Australia. Miner. Depos. 2018, 53, 477-492. [CrossRef]

134. Oreskes, N.; Einaudi, M.T. Origin of hydrothermal fluids at Olympic Dam: Preliminary results from fluid inclusions and stable isotopes. Econ. Geol. 1992, 87, 64-90. [CrossRef]

135. Haynes, D.W.; Cross, K.C.; Bills, R.T.; Reed, M.H. Olympic Dam ore genesis; a fluid-mixing model. Econ. Geol. 1995, 90, 281-307. [CrossRef]

136. Montreuil, J.-F.; Corriveau, L.; Potter, E.G.; De Toni, A.F. On the Relationship Between Alteration Facies and Metal Endowment of Iron Oxide-Alkali-Altered Systems, Southern Great Bear Magmatic Zone (Canada). Econ. Geol. 2016, 111, 2139-2168. [CrossRef]

137. Betts, P.G.; Valenta, R.K.; Finlay, J. Evolution of the Mount Woods Inlier, northern Gawler Craton, southern Australia; an integrated structural and aeromagnetic analysis. Tectonophysics 2003, 366, 83-111. [CrossRef]

138. Forbes, C.J.; Giles, D.; Jourdan, F.; Sato, K.; Omori, S.; Bunch, M. Cooling and exhumation history of the northeastern Gawler Craton, South Australia. Precambrian Res. 2012, 200-203, 209-238. [CrossRef]

139. Fabris, A.J.; Halley, S.; van der Wielen, S.; Keeping, T.; Gordon, G. IOCG-style Mineralisation in the Central Eastern Gawler Craton, SA; Characterisation of Alteration, Geochemical Associations and Exploration Vectors; Report Book 2013/00014; Department of Innovation, Manufacturing, Trade, Resources and Energy: Adelaide, Australia, 2013.

140. Benavides, J.; Kyser, T.K.; Clark, A.H.; Stanley, C.; Oates, C. Exploration guidelines for copper-rich iron oxide-copper-gold deposits in the Mantoverde area, northern Chile: The integration of host-rock molar element ratios and oxygen isotope compositions. Geochem. Explor. Environ. Anal. 2008, 8, 343. [CrossRef]

141. Dmitrijeva, M.; Ehrig, K.J.; Ciobanu, C.L.; Cook, N.J.; Verdugo-Ihl, M.R.; Metcalfe, A.V. Defining IOCG signatures through compositional data analysis: A case study of lithogeochemical zoning from the Olympic Dam deposit, South Australia. Ore Geol. Rev. 2019, 105, 86-101. [CrossRef]

142. Huang, Q.; Kamenetsky, V.S.; McPhie, J.; Ehrig, K.; Meffre, S.; Maas, R.; Thompson, J.; Kamenetsky, M.; Chambefort, I.; Apukhtina, O.1.; et al. Neoproterozoic (ca. 820-830 Ma) mafic dykes at Olympic Dam, South Australia: Links with the Gairdner Large Igneous Province. Precambrian Res. 2015, 271, 160-172. [CrossRef]

143. Baudet, E.; Giles, D.; Tiddy, C.; Hill, S. Evaluation of cover sequence geochemical exploration sample media through assessment of element migration processes. Ore Geol. Rev. 2018, 102, 449-473. [CrossRef]

144. Knutson, J.; Donnelly, T.H.; Tonkin, D.G. Geochemical constraints on the genesis of copper mineralization in the Mount Gunson area, South Australia. Econ. Geol. 1983, 78, 250-274. [CrossRef]

145. Cowan, D.; Dentith, M. Unconformity-related copper mineralisation on the Stuart Shelf, South Australia: Geophysical responses of mineralisation and the mineralised environment. ASEG Ext. Abstr. 2003, 2003, 197-212. [CrossRef]

146. Williams, P.J.; Kendrick, M.A.; Xavier, R.P. Sources of ore fluid components in IOCG deposits. In Hydrothermal Iron Oxide Copper-Gold E Related Deposits: A Global Perspective, v. 3-Advances in the Understanding of IOCG Deposits; Porter, T.M., Ed.; PGC Publishing: Adelaide, Austrilia, 2010; pp. 107-116.

147. Hand, M.; Reid, A.; Szpunar, M.; Direen, N.G.; Wade, B.; Payne, J.; Barovich, K. Crustal architecture during the early Mesoproterozoic Hiltaba-related mineralisation event: Are the Gawler Range Volcanics a foreland basin fill? MESA J. 2008, 51, 19-24.

148. Teale, G.S. Iron oxide copper-gold mineralisation styles from the Curnamona Province. In 2003 Broken Hill Exploration Initiative Abstracts from the July 2003 Conference; Peljo, M., Ed.; Geoscience Australia Record: Canberra, Australia, 2003; pp. 180-183. 
149. Wise, T.; Katona, L. Gravity anomalies as trap sites in prospectivity modelling of the eastern Gawler copper-gold belt. Aust. Soc. Explor. Geophys. Ext. Abstr. 2015, 1, 1-4. [CrossRef]

150. Katona, L.F.; Wise, T.; Reid, A.J. Vectorisation of Residual Gravity and TMI Data in the Northern Gawler Craton: Implications for Exploration Targeting and GIS Analysis; Report Book 2015/00003; Department for Energy and Mining: Adelaide, Australia, 2018.

151. Soe, S.; Lagat, C.; Evans, B.; Mostofi, M.; Fox, S. The coiled tubing drilling rig for mineral exploration. In Proceedings of the SPE/ICoTA Coiled Tubing and Well Intervention Conference and Exhibition, The Woodlands, TX, USA, 27 March 2018; p. 10.

C 2019 by the author. Licensee MDPI, Basel, Switzerland. This article is an open access article distributed under the terms and conditions of the Creative Commons Attribution (CC BY) license (http://creativecommons.org/licenses/by/4.0/). 